\title{
THE ROLE OF PROSTAGLANDINS IN THE REPRODUCTIVE PHYSIOLOGY OF THE RABBTT
}

JOHA PATRICK O'GRADY 


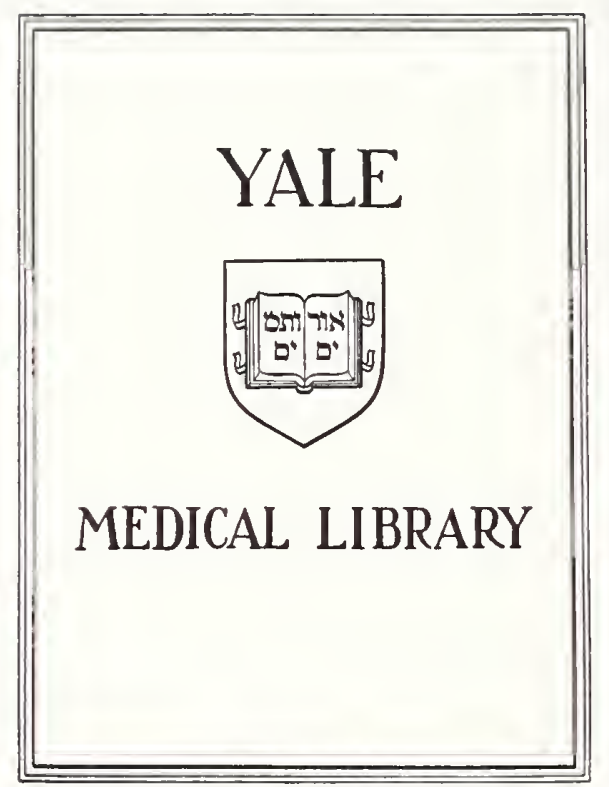



Digitized by the Internet Archive in 2017 with funding from

Arcadia Fund 


THE ROLE OF PROSTAGLANDINS IN THE REPRODUCTIVE PHYSIOLOGY OF THE RABBIT 

THE ROLE OF PROSTAGLANDINS IN THE REPRODUCTIVE PHYSIOLOGY OF THE RABBIT

\author{
A Thesis Submitted to the Faculty of the \\ Department of Obstetrics and Gynecology of Yale University, \\ School of Medicine \\ In Partial Fulfillment of the Requirements for the \\ Degree of Doctor of Medicine
}

by

John Patrick O'Grady

A.B. Stanford University, 1967

M.A. Stanford University, 1969

New Haven, Connecticut

March, 1972 



\section{ACKNOWLEDGEMENTS}

I record with pleasure my thanks to the many persons who have helped make the research reported in this paper possible.

Financial assistance was provided by the Ford Foundation, the Playboy Foundation, and the Educational Foundation of America.

I am endebted to Dr. Leon Speroff, Dr. E.I. Kohorn, and Dr. Burton Caldwell for generous investments in time, personal interest, and laboratory space. Their help in suggesting corrections, reading drafts and providing answers to numerous questions has been instrumental in completion of this report.

Dr. Robert Glass, Dr. N. Kase and Mr. William Brock provided both assistance and encouragement during the preparation of this work.

Special thanks also to Dr. F. Auletta for many operative and psychological assists.

Mr. Jon Gordon, and Ms. Miriam Kangas, Michelina Basile, Dawn Sassi, and Susan Hemperly gave generously of their time and expertise.

Finally, I would like to acknowledge the assistance of my wife, Jeanne Kelly O'Grady whose help in editing and criticizing this report was invaluable. 

ACKNOWLEDGEMENTS

Page

LIST OF TABLES

LIST OF ILLUSTRATIONS.

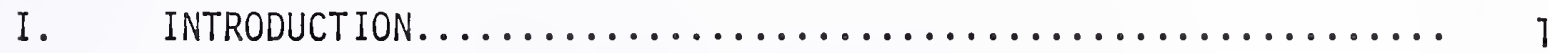

A. THE PROSTAGLANDINS......................... 1

B. PROSTAGLANDINS IN REPRODUCTIVE PHYSIOLOGY.......... 2

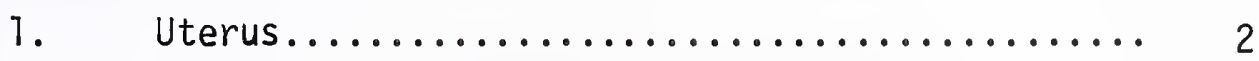

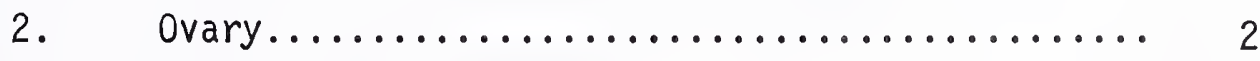

3. Pituitary.......................... 3

C. ADENYL CYCLASE SYSTEM...................... 4

D. EXPERIMENTAL MODEL....................... 4

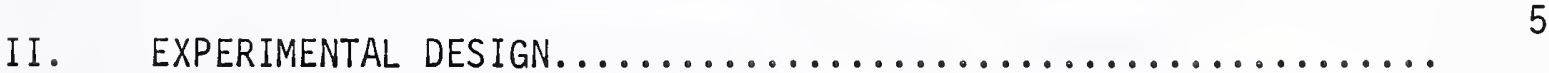

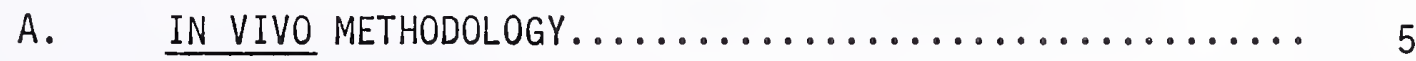

1. Gonadotropin Induced Ovulation............ 6

2. Coitus Induced Ovutation................ 6

3. Length of Pseudopregnancy.............. 7

4. Normat Pregnancy.................... 7

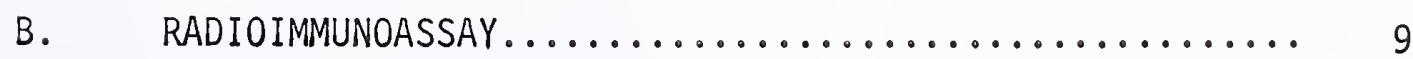

1. In Vivo Sampies..................... 9

2. In Vitro Samples................... 13

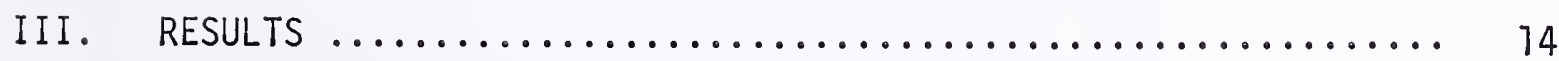

A. IN VIVO EFFECTS OF INDOMETHACIN.............. 14

1. Gonadotropin Induced Ovuiation........... 14

2. Coitus Induced Ovutation................ 17 

3. Length of Pseudopregnancy................ 19

4. Normal Pregnancy...................... 27

B. IN VITRO EFFECTS OF INDOMETHACIN.............. 22

1. Control Incubations.................. 22

2. Prostaglandin $F_{2 \alpha}$ Incubations............ 23

3. Prostaglandin $\mathrm{F}_{2 \alpha}$ /Human Chorionic Gonadotropin Incubations............... 24

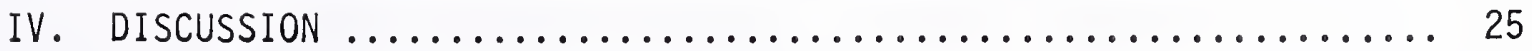

A. RABBIT REPRODUCTIVE PHYSIOLOGY.............. 25

1. Ovulation, Implantation and Pregnancy....... 25

2. Corpus Luteum Function................ 28

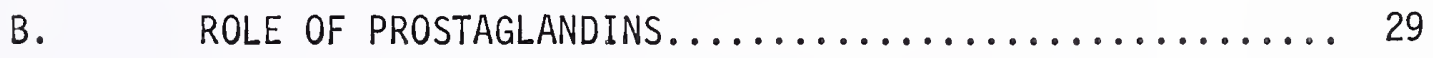

1. Prostaglandins and Ovulation............ 29

2. Prostaglandins and Corpus Luteum Regression.... 37

3. Prostaglandins and Normal Pregnancy......... 35

C. MECHANISM OF ACTION OF PROSTAGLANDINS ON LUTEAL

CELL FUNCTION.......................... 35

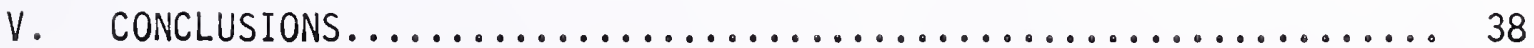





\section{LIST OF TABLES}

Table

1. The Influence of Indomethacin on Gonadotropin Induced Ovutation............................... 15

2. The Effect of Indomethacin on Coital Induced Ovulation.... 18

3. The Influence of Indomethacin on Normal Pregnancy........ 27

4. The Length of Pseudopregnancy in Rabbits Hysterectomized, Immunized against Prostaglandin $F_{2 \alpha}$ and Treated

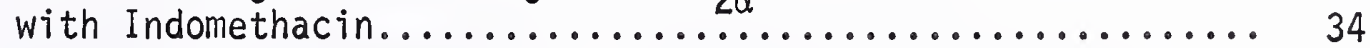





\section{LIST OF ILLUSTRATIONS}

Figure

1. Organ Culture System............................... 8

2. R-30 Progesterone Antibody Cross-Reactions............. 10

3. Separation of Neutral Steroids on Sephadex LH-20

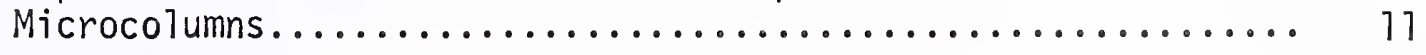

4. Hemorrhagic Follicles with Retained Ova in Animals Treated with Indomethacin........................ 16

5. Length of Pseudopregnancy in Indomethacin Treated Rabbits.... 20

6. Progestin Synthesis in a Modified Organ Culture System...... 22

7. Inhibition of In Vivo Progestin Synthesis by

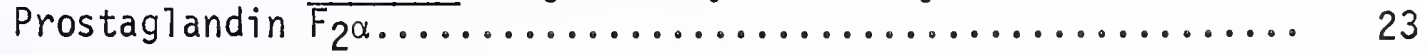

8. Antagonism of Prostaglandin $F_{2 \alpha}$ by Human Chorionic Gonad-

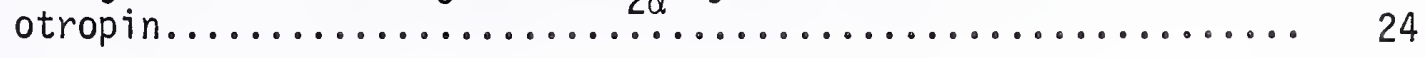

9. Steroid and Gonadotropin Levels in Normal Rabbits......... 26

10. Control of Corpus Luteum Biosynthesis at the Cellular Level.. 36 

THE ROLE OF PROSTAGLANDINS IN THE REPRODUCTIVE PHYSIOLOGY OF THE RABBIT 



\section{INTRODUCTION}

The Prostaglandins

The prostaglandins are a group of naturally occurring fatty acid derivatives active in many if not all animal organs. Prostaglandins have been implicated in an array of biological actions including contraction of myometrium and initiation of labor (Karim \& Filshie, 1970), dilation of bronchial musculature (Large et al, 1969), alterations in blood pressure (McGiff et al, 1970; Lee, 1967), regulation of steroid secretion from the ovary (Speroff \& Ramwe11, 1970a), inhibition of gastrin (Lippmann, 1970) and mediation of neural transmission (Siggins et al, 1971). In addition to these biological actions of prostaglandins it is known that neural and hormonal stimulation of many tissues results in prostaglandin release. This release of prostaglandins from biological tissues is believed to represent new biosynthes is from fatty acid precursors and not simply the escape of the stored lipid (Piper \& Vale, 1971).

A striking feature of prostaglandins in biological systems is their potency and brief half-life. Prostaglandins are physiologically active in pg to ng concentrations and in vivo, a single passage through the lungs or liver inactivates $90 \%$ of an administered dose (Ferreira et al, 1967; Piper et a1, 1970). 



\section{Prostaglandins in Reproductive Physiology}

Reproductive physiology is a major area for prostaglandin research. These compounds have been shown to influence uterine, ovarian, and pituitary functions in several species. To serve as a basis for the design of the present experiments, a brief review of the previous research in this area will be presented.

Uterus

Prostaglandins have long recognized effects on the myometrium, dependent upon the phase of the normal cycle or the existence of pregnancy. Intravenous (Wiqvist et al, 1970), intravaginal (Karim, 1971) and intraamniotic (Bygdeman \& Wiqvist, 1971; Anderson et a1, 1972) administration of prostaglandins produces uterine contractions sufficient to abort immature fetuses. In addition, while progesterone blocks oxytocin induced uterine contractions it fails to prevent prostaglandin induced contractions (Anderson et a1, 1972). This observation has suggested that the prostaglandins may actualiy be the mediators of oxytocin in the induction of normal labor.

Ovary

Prostaglandins are also believed to be important in ovarian function, both at the organ level as well as in the hypothalamic/pituitary gonadotropin control mechanisms (Kueh1 et a1, 1970; Marsh, 1971). For example, in vivo and in vitro studies in several species have documented that prostaglandins can produce striking and rapid alterations in ovarian steroidogenesis. Speroff and Ramwell (1970b) have shown a significant stimulation of progesterone production with bovine corpora lutea in vitro 

by prostaglandin $E_{1}$ and $E_{2}$ with some stimulation also noted with prostaglandin $F_{2 \alpha}\left(P G F_{2 \alpha}\right)$. In addition, Pharriss (Pharriss et al, 1972) has postulated that in vivo prostaglandins may be "luteolysins" responsible for normal corpus luteum regression. Finally, new experiments with inhibitors of prostaglandin synthesis have implicated prostaglandins in the process of ovulation in the rat at the pituitary and ovarian level (Armstrong \& Grinwich, 1972; Orczyk \& Behrman, 1972).

\section{Pituitary}

Recent experimental evidence suggests the involvement of prostaglandins in the pituitary regulation of gonadotropin release. Luteinizing Hormone (LH) concentration in the pituitary is increased by $P G F_{2 \alpha}$ (Labhsetwar, 1970). Also, LH release, stimulated by LH releasing factor (LRF) is blocked in vitro by 7-oxa-13-prostynoic acid, a prostaglandin antagonist (Amoss et a1, 1971).

In in vivo rat experiments utilizing a potent inhibitor of prostaglandin synthesis, indomethacin, 1-[p-ch1oro-benzoy 1]-5-methoxy-2-methy 1 indole-3-acetic acid (Vane, 1971), Behrman's group has shown reduced prostaglandin concentration in the pituitary and hypothalamus (Orczyk \& Behrman, 1972). Moreover, ovulation could be blocked by indomethacin treatment, and this effect was reversable with a mixture of $\mathrm{PGE}_{2} / \mathrm{PGF}_{2 \alpha}$, or with LH, suggesting that in the rat this ovulatory blockade was at the pituitary level. Aspirin (acetyl salicyclic acid) which has also been shown to be an inhibitor of prostaglandin synthesis when given in large doses was also able to block ovulation. LRF was unable to overcome the inhibition of ovulation due to indomethacin but could overcome the block imposed with aspirin (Behrman, personal communication). 



\section{Adeny 1 Cyclase System}

Prostaglandins have been implicated as regulators of several biological systems and many of their varied effects are believed to be mediated through control of cyclic adenosine monophosphate (CAMP) production (Ramwel1 \& Shaw, 1971). Prostaglandins increase the concentration of CAMP in tissues of the rat (Butcher \& Bard, 1968), guinea pig (Perrier \& Laster, 1970), and dog (Field et a1, 1969), and this effect has in general been associated with increased adenyl cyclase activity (Shaw et a7, 1971). However, in fat cells and in platelets, prostaglandins have been reported to act as inhibitors of the CAMP system (Shio et a7, 1972). In the mouse ovary, a prostaglandin antagonist blocks both LH and prostaglandin mediated increases in CAMP (Kuehl et al, 1970). This evidence suggests that prostaglandins may function as messengers between an $\mathrm{LH}$ effect and the activation of adenyl cyclase.

\section{Experimental Mode1}

Much of the past confusion regarding the role of prostaglandins as regulators in reproductive physiology has resulted from the use of many species, and many tissues in a multitude of experimental designs. The purpose of the present work is to explore the role of prostaglandins in a single species, correlating our findings with previously accepted physiological observations to increase the understanding of the complexities of normal reproductive function in a single animal. This type of data could then form the basis for meaningful comparisons of reproductive physiology between common laboratory animals. 

A series of in vitro experiments, utilizing a modified organ culture system was devised to evaluate the direct involvement of prostaglandins in luteal function. On the basis of these results, in vivo experiments with indomethacin, an inhibitor of prostaglandin synthesis, were developed to gauge the involvement of prostaglandins in normal reproductive physiology. The role of prostaglandins was investigated in ovuiation, in the regression of the corpus luteum of pseudopregnancy, and in the course of normat pregnancy.

\section{EXPERIMENTAL DESIGN}

\section{In Vivo Methodology}

Human chorionic gonadotropin (HCG, A.P.L., Ayerst Laboratories, Inc., New York, N.Y.) and luteinizing hormone (LH, Human, NIH-Lot A.2, National Pituitary Agency, Baltimore, Maryland) were given intravenously and indomethacin was administered intravenous $7 y$ or subcutaneous $7 y$ as indicated in the experimental protocol which is presented in the Results.

Indomethacin for subcutaneous injection was prepared by emptying twenty $50 \mathrm{mg}$ Indocin (indomethacin, MSD, Merck, Sharp \& Dohme, West Point, Pa.) capsules into $10 \mathrm{ml}$ of USP sesame 011 ((Benne) Fisher Scientific Company, Fairiawn, N.J.) and vortexing the mixture vigorousiy for several minutes. The final concentration was $70 \mathrm{mg} / \mathrm{mr}$ suspension.

Once prepared, the suspension was refrigerated at $4^{\circ} \mathrm{C}$. Sterile \#19 gauge hypodermic needles on standard disposable, sterile plastic tubercul in syringes were used to draw up and administer the preparation.

Intravenous indomethacin was produced by combining capsule contents with a gelatin phosphate buffer solution which was then adjusted to $\mathrm{pH} 8.0$. Buffer was produced by dissolving $5.38 \mathrm{~g} \mathrm{NaH}_{2} \mathrm{PO}_{4} \cdot \mathrm{HOH} ; 16.35 \mathrm{~g} \mathrm{Na}_{2} \mathrm{HPO}_{4}{ }^{\circ}$ $\mathrm{HOH} ; 9.0 \mathrm{~g} \mathrm{NaCL}$; and $7.0 \mathrm{~g}$ Knox Gelatin in 7 liter of distilled water. 

One ml penicillin/streptomycin solution $-5,000$ iu penicillin and (Grand Island Biological Co., Grand Island, N.Y.) 5,000 mcg streptomycin/m7- was added to each $250 \mathrm{ml}$ of prepared solution prior to its refrigeration at $4^{\circ} \mathrm{C}$. Final prepared concentration was $50 \mathrm{mg} / \mathrm{ml}$.

Animals explored surgically were anesthetized with $1.75-2.5 \mathrm{~m} 1$ pentobarbitol intravenous $7 y$ and laparatomy was performed through a midline abdominal incision. For sacrifice, rabbits were injected intravenously with 4-6 m7 pentobarbitol.

Ovaries removed in surgical procedures were placed in 10\% Formalin solution for subsequent histological examination.

Blood samples were drawn with a \# 23 hypodermic needle and a $5 \mathrm{cc}$ syringe by cardiac puncture or via an ear artery. Blood samples were extracted and assayed for progestin content by radioimmunoassay.

Mature New Zealand white rabbits with a weight of 3.5 to $4.5 \mathrm{~kg}$ were housed under conditions of constant lighting, humidity, and temperature and were randomly selected for use in a series of four in vivo experiments. The precise timing and dosage of drugs and gonadotropins utilized are described in the Results.

Gonadotropin Induced Ovulation

Animals were given doses of indomethacin at varying times prior to or following the administration of ovulatory doses of exogenous gonadotropins. The rabbits were explored surgically and the ovaries examined 2-4 days after treatment.

Coitus Induced Ovulation

Experimental animals were treated with indomethacin both before and after coitus. Ovaries were examined at laparatomy 2-6 days post mating. 

Length of Pseudopregnancy

Rabbits were made pseudopregnant with exogenous gonadotropins. Indomethacin was administered during the course of pseudopregnancy white plasma samples were drawn for progestin determination.

\section{Normal Pregnancy}

Pregnant animals were treated with indomethacin throughout a period of their gestation. Laparatomy was performed at varying times to evaluate fetal viability.

\section{In Vitro Methodology}

New Zealand white rabbits similar to those used in the in vivo studies were randomly selected for mating with different males. On the tenth day post coitus, the ovaries were removed surgically. The corpora lutea were dissected free and then bisected and transferred to an organ culture dish (c.f. O'Grady et al, 1972).

Corpora lutea were incubated under controthed conditions with PGF $2 \alpha$ and HCG. The incubation medium was removed at regular intervals and both the medium and the tissue slices were assayed for progestin content.

In the organ culture system, each piece of tissue was placed upon a circle of Gelman paper which rested on a metal grid in contact with a nutrient bath in a plastic culture dish (Falcon Plastics, Division of Bioquest, Los Angeles, California). The nutrient was surrounded by a ring of blotter paper saturated with $5 \mathrm{ml}$ of sterile distilled water to maintain humidity (Text-Figure 1).

The nutrient medium consisted of 90\% Medium 199 (Earle's base with glutamine and $2.2 \mathrm{~g} / 1 \mathrm{NaHCO}_{3}$, Grand Island Biological Company, Grand Island, N.Y.) and $10 \%$ sterile lyophilized rabbit serum (DIFCO Laboratories, 

Detroit, Michigan) adjusted to $\mathrm{pH} 7.45$.

Text Figure 1

ORGAN CULTURE SYSTEM

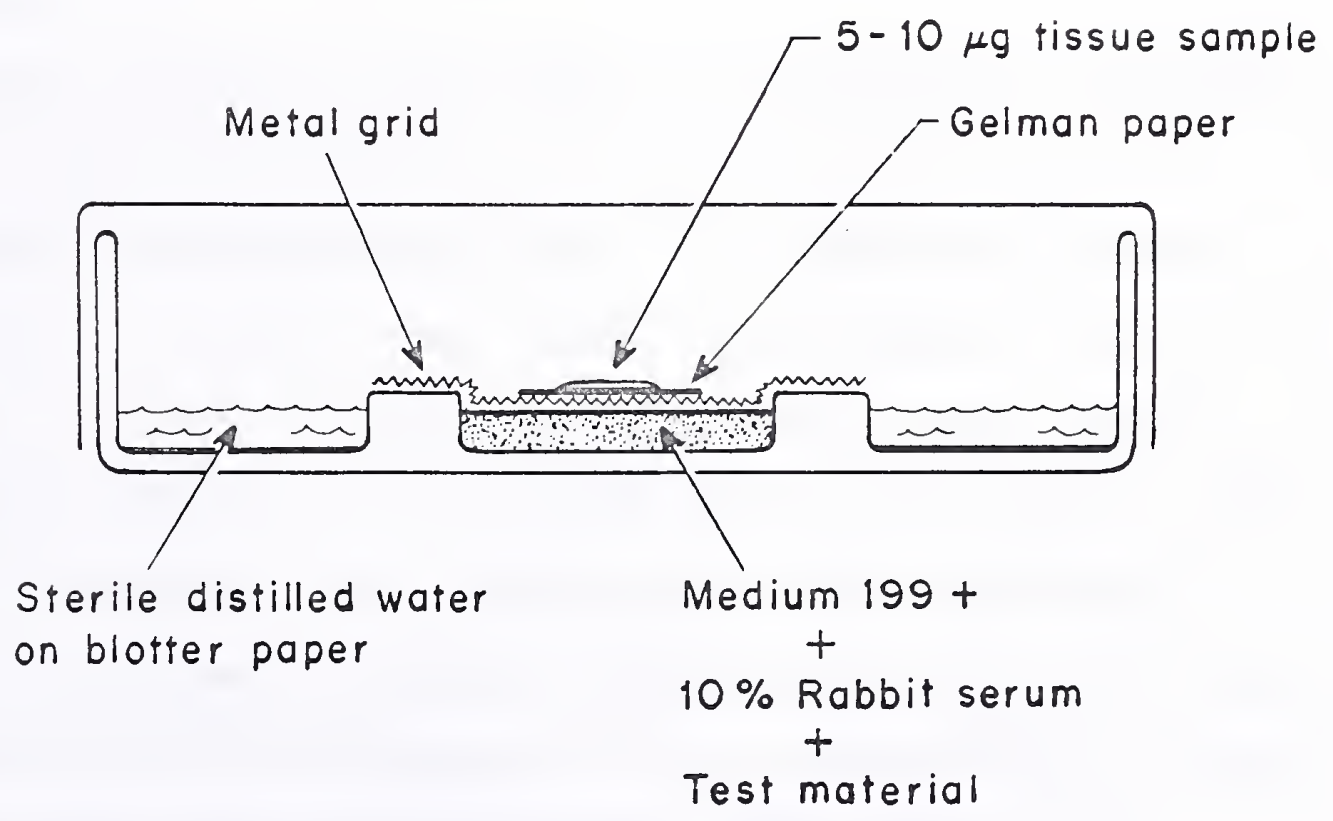



Materials to be tested were added to the solution. One milliliter of medium was used to fill the central well of the culture dish to maintain the sample during incubation.

Prepared dishes were placed in an air tight plastic box and maintained at $37^{\circ} \mathrm{C}$ in an incubating oven (Nationar Appliance Company, Portland, Oregon, Mode1 3221). During incubation $95 \% \mathrm{O}_{2}$ and $5 \% \mathrm{CO}_{2}$ was continuousiy suppiied to the plastic box by tubing. Medium samples and incubated tissue were frozen at $20^{\circ} \mathrm{C}$ for subsequent progestin anarysis.

\section{RADIOIMMUNOASSAY}

In Vivo Samples

Progesterone content of serum samples was determined by radioimmunoassay using an antiserum prepared in collaboration with Dr.'s Nikhail and Flickenger of the University of Pennsylvania against progesterone linked through an oxime bond at the 3 position and coupled to bovine serum albumin. The only steroids showing a significant cross reaction

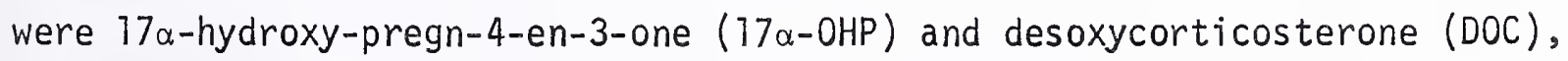
$25 \%$ and $10 \%$ respectiveiy. Cross reactivity of the antisera with $20 \alpha-$ hydroxy-pregn-4-en-3-one (20a-dihydroprogesterone) was only $1 \%$ (Text Figure 2). Progesterone and 20a-dihydroprogesterone are the primary synthetic products of the rabbit ovary (Dorrington \& Kilpatrick, 1969), and since DOC and 17a-OHP are essential1y absent from this organ, the assay as used measured progesterone almost exclusively.

A typical standard curve for the progesterone determinations showed a slope linear from $20-1000 \mathrm{pg}$, and a sensitivity of $20 \mathrm{pg}$ was achieved with a negligible blank value. 

Text Figure 2

R-30 PROGESTERONE ANTIBODY CROSS-REACTIONS

\begin{tabular}{|c|c|c|c|}
\hline STEROID & $1 \mathrm{ng}$ & $10 \mathrm{ng}$ & $100 \mathrm{ng}$ \\
\hline ET & $0.0 \%$ & $0.0 \%$ & $0.7 \%$ \\
\hline E2 & 0.0 & 0.0 & 0.7 \\
\hline E3 & 0.7 & 0.7 & 0.15 \\
\hline TESTO & 0.7 & 0.1 & 0.26 \\
\hline DHT & 0.7 & 1.2 & 0.5 \\
\hline ANDRO & 0.0 & 0.0 & 0.7 \\
\hline PREG & 0.7 & 3.2 & 0.3 \\
\hline ALDO & 0.0 & 0.0 & 0.0 \\
\hline $20 \alpha$ & 0.7 & 1.0 & 1.0 \\
\hline $\mathrm{CH}$ & 0.0 & 0.0 & 0.1 \\
\hline CORTISOL & 0.7 & 0.1 & 0.1 \\
\hline DOC & 25.0 & 8.0 & 10.0 \\
\hline PROG & 100.0 & 100.0 & 100.0 \\
\hline $17 \alpha$ & 30.0 & 7.5 & 0.76 \\
\hline CMPD. S & 0.0 & 0.0 & 0.0 \\
\hline
\end{tabular}



Blood samples from the test animals were centrifuged at 2,000 rpm for 5 minutes. The serum was decanted into clean tubes and then frozen at $-20^{\circ} \mathrm{C}$ for subsequent analysis. The serum was extracted with diethy 1 ether and separated by Sephadex microcolumn elution prior to assay using a procedure modified from Carr et a1, 1971 (Text Figure 3).

Text Figure 3

SEPARATION OF NEUTRAL STEROIDS ON SEPHADEX LH-2O MICROCOLUMNS

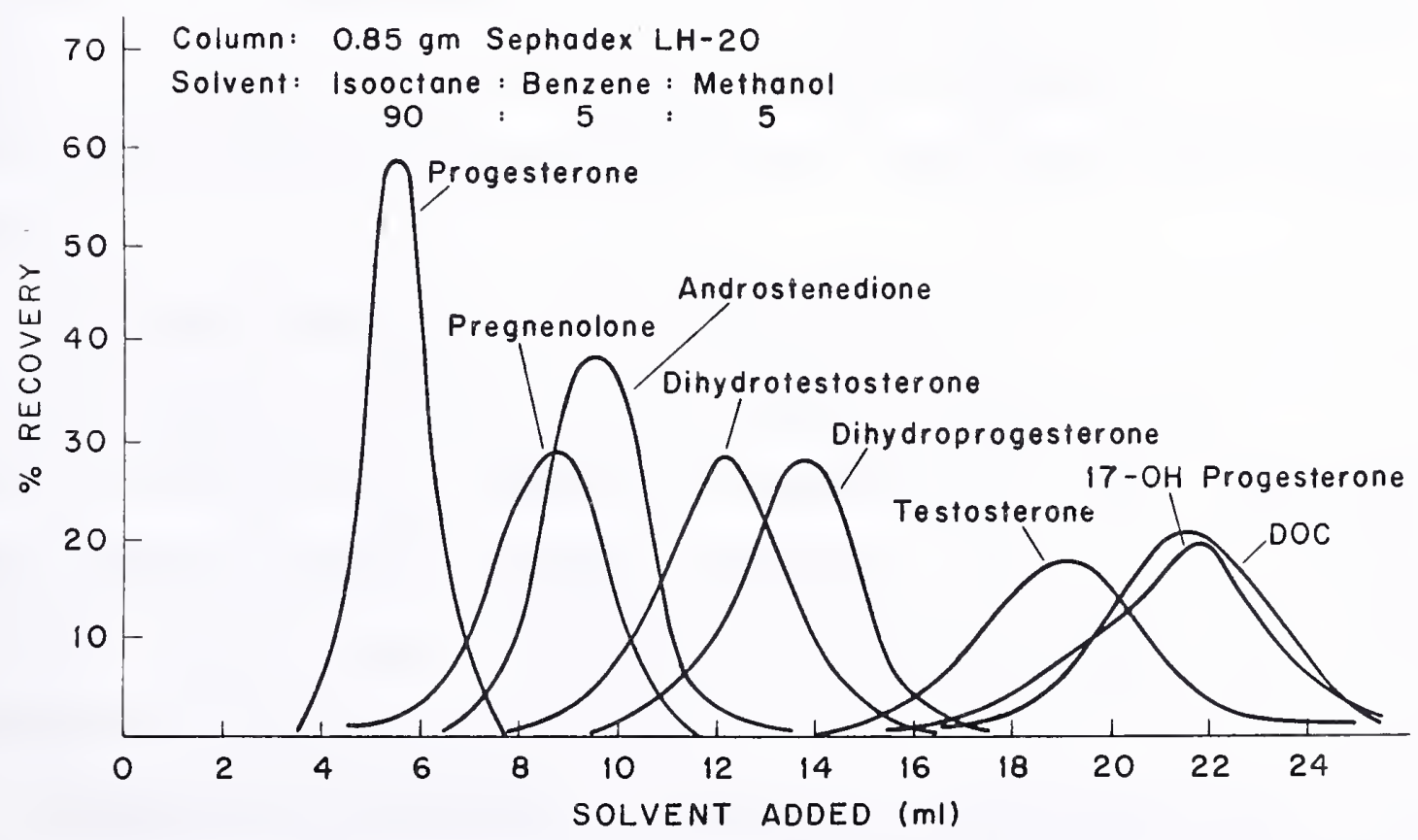



A trace amount of progesterone ${ }^{3} \mathrm{H}(800-1000 \mathrm{cpm})$ in ethanol solution was added to glass extraction tubes and evaporated to dryness under air. A consistent $65-75 \%$ efficiency of recovery was achieved through a 11 procedures.

One $\mathrm{ml}$ of serum sample was added to each extraction tube followed by $8 \mathrm{~m} 1$ of diethy 1 ether. The tubes were tightly stoppered and shaken vigorously for 60 seconds. Following 5 minutes of centrifugation at 2,000 rpm, the upper ether layer was pipetted into a conical centrifuge tube and evaporated to dryness under air.

Sephadex LH-20 microcolumns were prepared by slurrying $0.85 \mathrm{~g}$ Sephadex LH-20 (Pharmacia Fine Chemicals, Inc., Piscataway, N.J.) in a 90:10 (benzene:methano1) solution. This suspension was pipetted into a blown glass microcolumn $(1.0 \times 15 \mathrm{~cm})$, plugged with a circle of glass fiber filter paper. Once the Sephadex had been transferred to the microcolumn, the tube was washed with 90:5:5 (iso-octane:benzene:methano1) solution.

The serum sample extracts were redissolved with $0.2 \mathrm{ml}$ of $90: 5: 5$ solution and applied to the Sephadex columns. Four milliliters of 90:5:5 solution was then added to each column and the eluate discarded. Each column was then washed with an additional $5 \mathrm{ml}$ of $90: 5: 5$ solution applied in small aliquots. This final fraction was collected and redissolved in $2 \mathrm{ml}$ of ethanol.

Aliquots $(0.4$ and $0.8 \mathrm{ml})$ of the ethanol solution were then pipetted into $10 \times 75 \mathrm{~mm}$ disposable glass culture tubes. The $0.8 \mathrm{ml}$ remaining was used for estimation of recovery. These tubes were evaporated to dryness under air and assayed for progesterone by adding antibody and $\left({ }^{3} H\right)$ progesterone along with aliquots of phosphate buffer solution $(0.7 \mathrm{~m})$. 



\section{In Vitro Samples}

Progestins in in vitro samples were also measured by radioimmunoassay, using essentially the same method as previously described.

The culture media were assayed by adding antibody and $\left({ }^{3} H\right)$ progesterone along with aliquots of the diluted medium $(1:: 2.5)$ into $10 \times 75 \mathrm{~mm}$ glass culture tubes.

Tissue samples were homogenized in $1.0 \mathrm{ml}$ of culture media with an all glass tissue grinder. The homogenate was diluted 1::10 and aliquoted for assay as above.

Sample tubes from both in vivo and in vitro experiments were equilibrated at $4^{\circ} \mathrm{C}$ for one hour and the antibody bound was separated from free $\left({ }^{3} \mathrm{H}\right)$ progesterone with $1 \mathrm{ml}$ of a dextran-coated charcoal suspension (0.025\% dextran--0.25\% charcoal) (Speroff et a. 1972 ). Following centrifugation -- 4 minutes at 2,200 rpm--, the bound fraction was decanted into a glass scintillation vial and $10 \mathrm{ml}$ of Aquasol (New England Nuclear, Pilot Chemicals Division, Boston, Massachusetts) was added. Samples were then counted for ten minutes on a liquid scintillation spectrophotometer (Packard Liquid Spectrophotometer, Mode] 3375). Standard curves for both antibody systems were plotted by linear regression of logit vs. $\log$ dose. 



\section{RESULTS}

\section{In Vivo Effects of Indomethacin}

Gonadotropin Induced Ovulation

Ovulatory intravenous doses of HCG were not blocked by concomitant single doses of indomethacin of 5,8 , or $20 \mathrm{mg} / \mathrm{kg}$ given intravenous $7 y$ (i.v.), unless additional indomethacin ( $8 \mathrm{mg} / \mathrm{kg}$ given subcutaneous $7 y$ every 12 hours) was administered subcutaneously (s.c.) over a 48 hour period following the HCG (Experiments 1 and 2 in Table I).

In animals treated with the prolonged course of indomethacin (experiment 2 in Table I) normal corpora lutea were absent, and hemorrhagic follicles were abundant. Histologic examination of these hemorrhagic follicles at laparotomy on day 3-6 revealed Tuteinization of the follicles with failure of egg expulsion, i.e. the development of corpora lutea with entrapment of the ova (Text Figure 4). It is on the basis of this observation of hemorrhagic, Tuteinized follicles with retained ova that a blocking effect of indomethacin on ovulation was substantiated.

In experiment 3 (Table I) ovulation was blocked in 4 of the 4 animals given $20 \mathrm{mg} / \mathrm{kg}$ of indomethacin i.v. 30 minutes before injection of an ovulatory dose of human LH (50 IU). Failure of ovulation was determined as above with the absence of normal corpora lutea and the presence of hemorrhagic, Juteinized follicles with retained ova in animals sacrificed at day 2-4. Control animals ovulated normally with this dose of HCG. 



\section{Table I}

THE INFLUENCE OF INDOMETHACIN ON GONADOTROPIN INDUCED OVULATION

\begin{tabular}{lll} 
& & \multicolumn{2}{c}{ OVARIAN RESPONSE* } \\
EXPERIMENT N TREATMENT SCHEDULE NORMAL HEMORRHAGIC NORMAL/TOTAL
\end{tabular}

\begin{tabular}{|c|c|c|c|c|c|}
\hline 1 & 14 & $\begin{array}{l}\text { 1. HCG Time } 0(20-200 \mathrm{IU}) \\
\text { 2. Indo. Time } 0(20 \mathrm{mg} / \mathrm{kg})\end{array}$ & 14 & 0 & $14 / 74$ \\
\hline 2 & 5 & $\begin{array}{l}\text { 1. HCG Time } 0(50 \mathrm{IU}) \\
\text { 2. Indo. Time } 0(20 \mathrm{mg} / \mathrm{kg}) \\
\text { 3. Indo. at } 12,24,36 \& 48 \\
\text { hours after }(8 \mathrm{mg} / \mathrm{kg})\end{array}$ & 0 & 5 & $0 / 5$ \\
\hline 3 & 4 & $\begin{array}{l}\text { 1. LH Time } 0(50 \mathrm{IU}) \\
\text { 2. Indo Time } 0(20 \mathrm{mg} / \mathrm{kg})\end{array}$ & 0 & 4 & $0 / 4$ \\
\hline
\end{tabular}



Text Figure 4

HEMORRHAGIC FOLLICLES WITH RETAINED OVA IN ANIMALS

TREATED WITH INDOMETHACIN
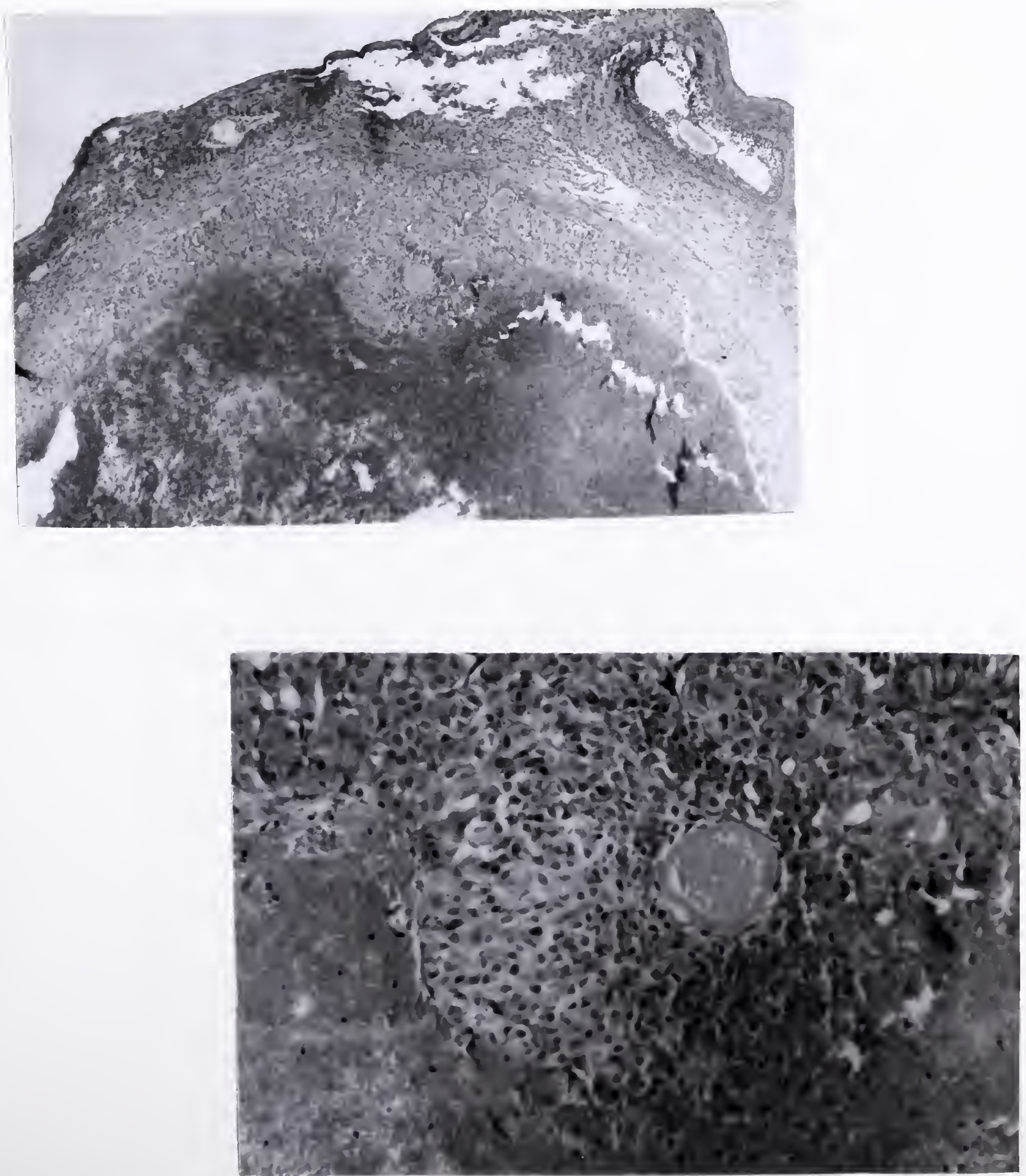

Coitus Induced Ovulation

Animals normally mated and treated with indomethacin $(8 \mathrm{mg} / \mathrm{kg}$ every 12 hours) for 36 hours pre-coitus, or receiving indomethacin $8 \mathrm{mg} / \mathrm{kg}$ intravenousiy at the time of coitus, developed normal corpora lutea as determined at laparotomy day 2-4 (Experiments 1 and 2, Table II).

In experiment 3 of Table II, animals were normally mated and treated with $20 \mathrm{mg} / \mathrm{kg}$ indomethacin 30 minutes pre-coitus with an additional intravenous dose of $20 \mathrm{mg} / \mathrm{kg} 8$ hours post-coitus or as in experiment 4, animals were given $20 \mathrm{mg} / \mathrm{kg}$ indomethacin i.v. only once, at 8 hours postcoitus. All of the animals in experiments 3 and 4 failed to ovulate. 



\section{Table II}

THE EFFECT OF INDOMETHACIN ON COITAL INDUCED OVULATION

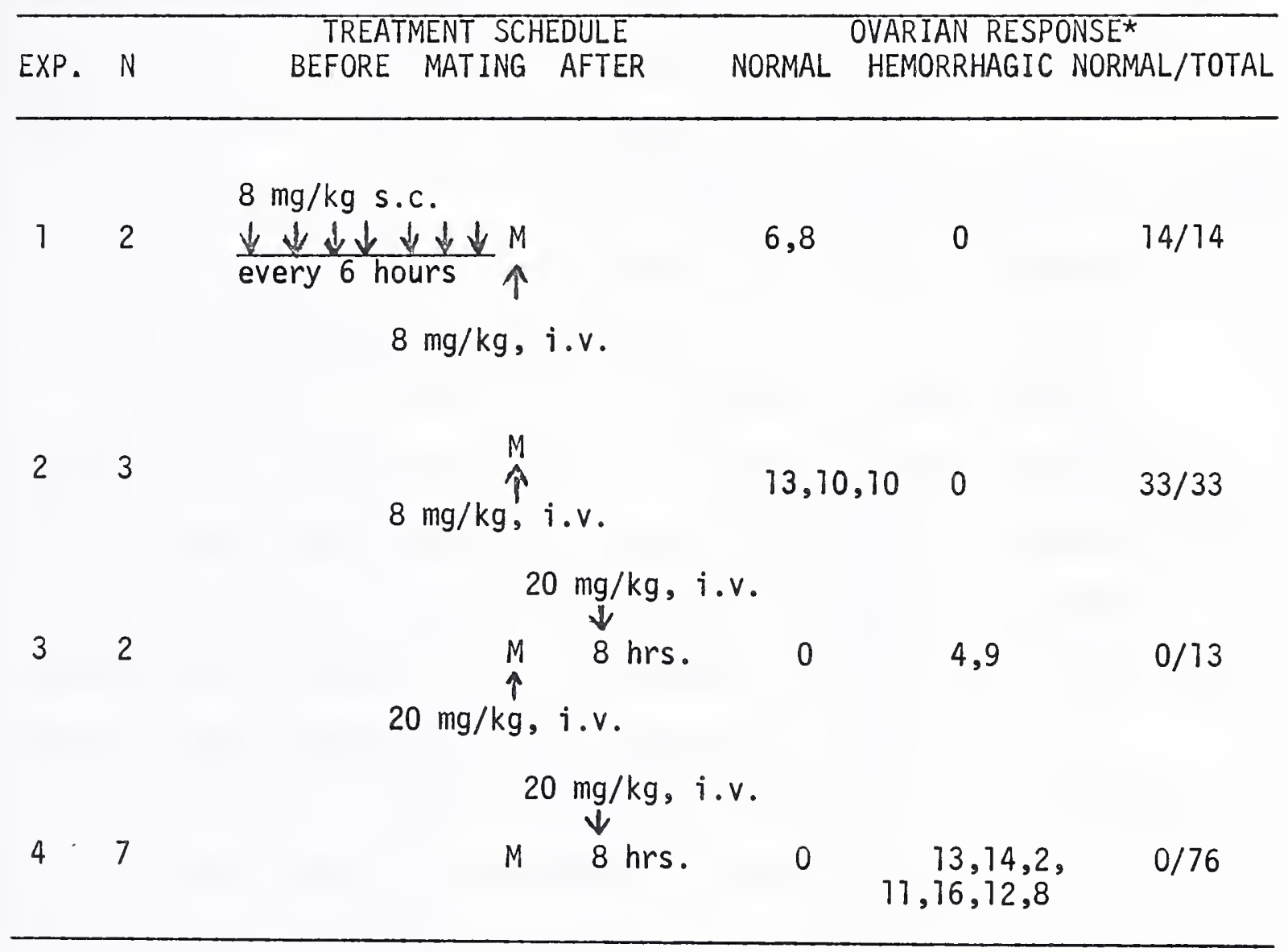

*

NORMAL: Corpora lutea with central ovulatory rupture sites

HEMORRHAGIC: Hemorrhagic follicles with no ovulatory rupture sites 

A11 the indomethacin treated animals who failed to ovulate from both exogenous (NIH-Human LH, or HCG) and endogenous stimuli (coitus) formed hemorrhagic follicles. In animals sacrificed after day 5, these hyperemic follicles were found to undergo luteal change and to become indistinguishable from ovulatory corpora lutea.

For the purposes of this study, determination of successful ovulation was made by gross observation of ovaries at sacrifice or laparotomy for the presence of ovulatory rupture sites.

The validity of determination of ovulation by observation of rupture sites is supported by Grinwich \& Armstrong (1972) who found by oviduct washing techniques that ova were present in 5 of 5 animals with rupture papillae. In addition, by oviduct lavage and microscopic examination of washings, these workers were able to recover $80 \%$ of the number of eggs diagnosed on gross examination to have ovulated.

In contrast, in animals developing hemorrhagic follicles without rupture sites oviduct lavage failed to recover any ova.

Length of Pseudopregnancy

Pseudopregnancy was induced in 7 animals by the intravenous injection of HCG (200 IU). Indomethacin ( $8 \mathrm{mg} / \mathrm{kg}$ ) was administered subcutaneous $7 y$ every 12 hours beginning on day 13 of pseudopregnancy. Peripheral levels of progesterone measured in 4 of the animals revealed that the corpora lutea continued to function beyond the norma 716 day limit for pseudopregnancy in rabbits (Text Figure 5 ).

Laparotomies performed on days 20 to 26 revealed grossly normal corpora 7utea. However, the reduced progesterone levels indicated that steroid secretory function was diminished. 



\section{Text Figure 5}

LENGTH OF PSEUDOPREGNANCY IN INDOMETHACIN TREATED RABBITS

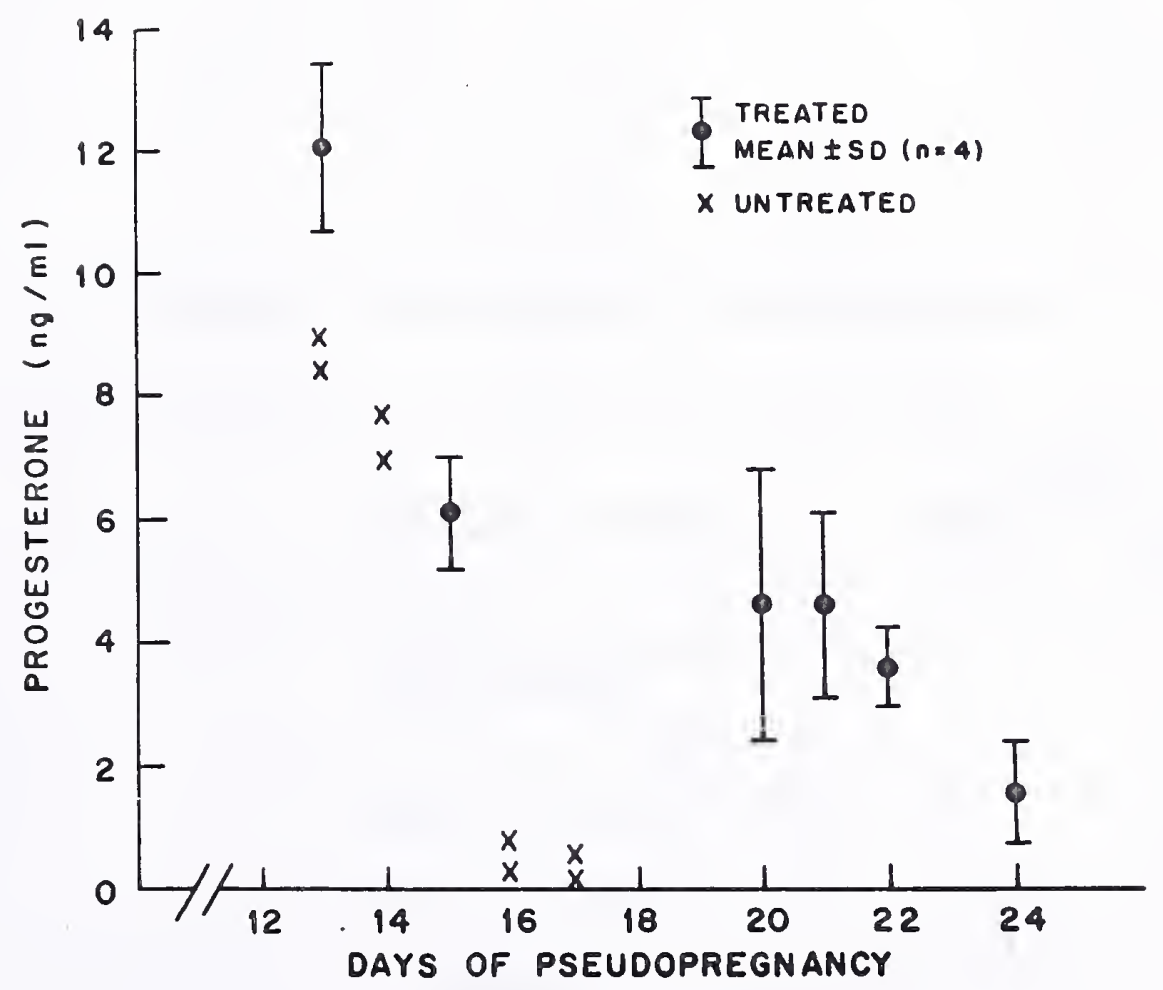



Normal Pregnancy

Treatment of 5 normally mated animals with indomethacin, $16 \mathrm{mg} / \mathrm{kg} / \mathrm{day}$, s.c. from day of mating resulted in reabsorption of 46 of 47 implanted fetuses detected when the uteri were examined at laparotomy (22-29) (Table III)

Treatment with $8 \mathrm{mg} / \mathrm{kg} /$ day indomethacin s.c. from day of mating was associated with the resorption of 18 of 23 implants (Experiment 2, Table III). Control animals injected with $0.5 \mathrm{cc}$ sesame oil on the same schedule developed normal implants which did not resorb (Experiment 3, Table II).

Table III

THE INFLUENCE OF INDOMETHACIN ON NORMAL PREGNANCY

\begin{tabular}{|c|c|c|c|c|}
\hline EXPERIMENT & $N$ & TREATMENT SCHEDULE & $\begin{array}{l}\text { FETL } \\
\text { NORMAL }\end{array}$ & $\begin{array}{l}\text { JSES } \\
\text { RESORBING }\end{array}$ \\
\hline 1 & 5 & $\begin{array}{l}16 \mathrm{mg} / \mathrm{kg} / \text { day from } \\
\text { day of mating }\end{array}$ & 1 & 46 \\
\hline 2 & 2 & $\begin{array}{l}8 \mathrm{mg} / \mathrm{kg} / \text { day from } \\
\text { day of mating }\end{array}$ & 5 & 78 \\
\hline 3 & 2 & $\begin{array}{c}.5 \text { cc sesame oit } \\
\text { from day of } \\
\text { mating }\end{array}$ & 23 & 0 \\
\hline
\end{tabular}





\section{In Vitro Effects of Indomethacin}

Control Incubations

Progestin content in unincubated and incubated rabbit corpus luteum samples are compared in Text Figure 6 . The tissue content showed a significant increase in total progestins $(p<.01)$ occurring during the period of incubation. However, only a small percentage of this increase was reflected in progestin output into the medium. This magnitude of increase in progestin content could only be the result of active progestin synthesis, verifying that the technique maintained tissue viability with active steroidogenesis.

Text Figure 6

PROGESTIN SYNTHESIS IN A MODIFIED ORGAN CULTURE SYSTEM

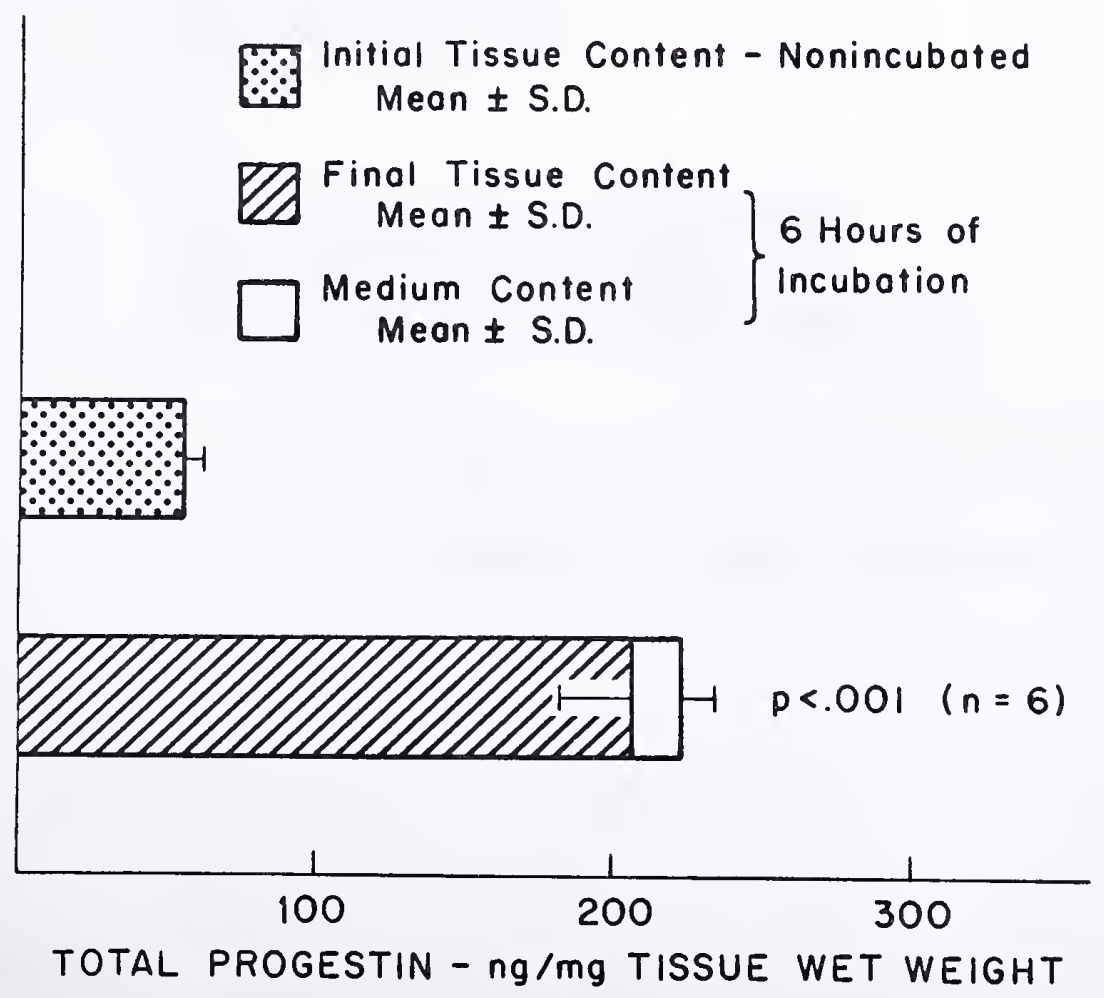



Prostaglandin $\mathrm{F}_{2^{\alpha}}$ Incubations

Text Figure 7 indicates the result of a series of experiments incubating tissue samples with $10 \mathrm{gg} / \mathrm{m} 1$ prostaglandin $F_{2 \alpha}$. The effect of this prostaglandin is to significantly inhibit progestin production by approximately $50 \%(p \leq .07)$.*

Text Figure 7

INHIBITION OF IN VIVO PROGESTIN SYNTHESIS BY PROSTAGLANDIN $F_{2 \alpha}$

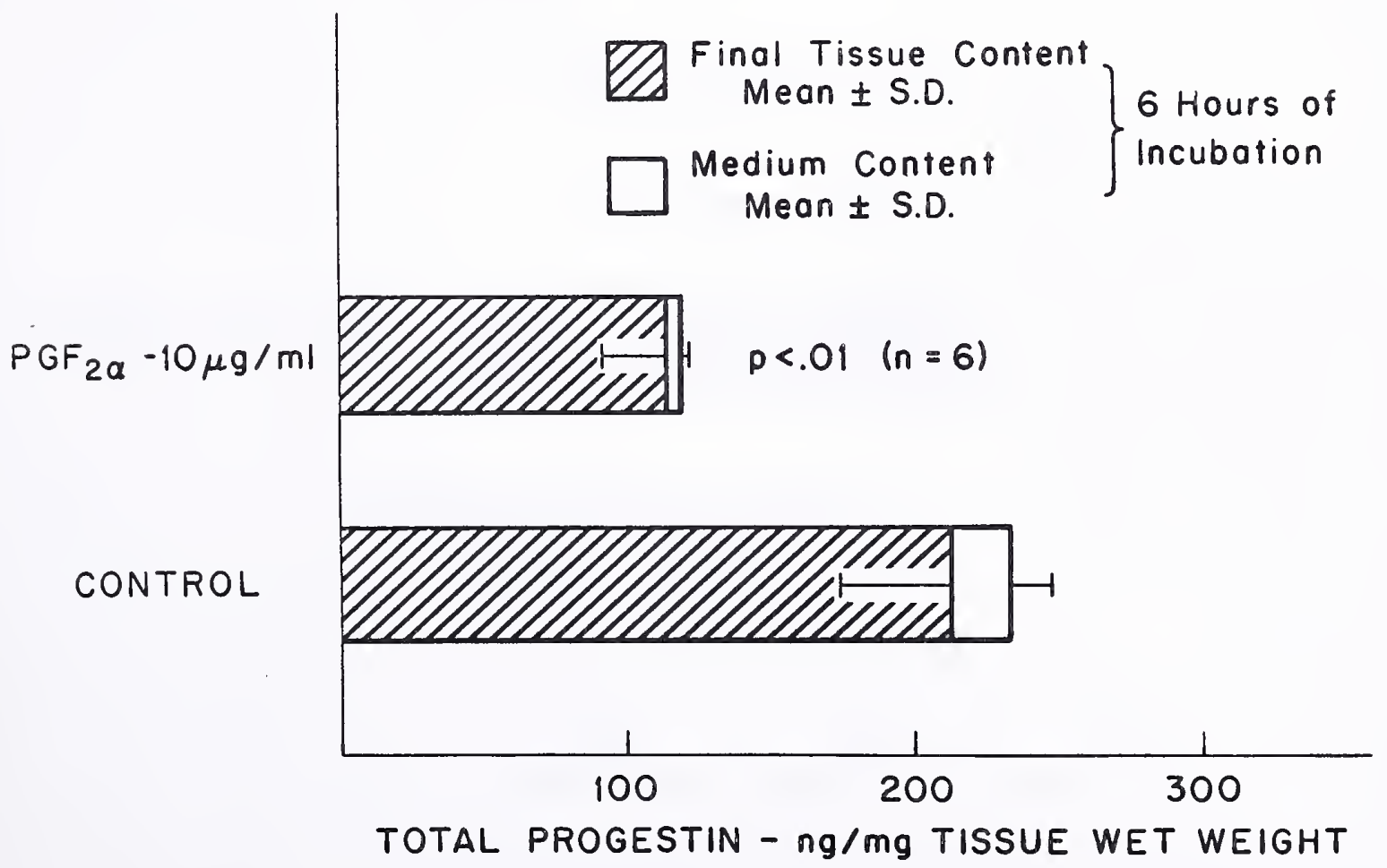

* Student's t-test 

Prostaglandin $\mathrm{F}_{2 \alpha}$ /Human Chorionic Gonadotropin Incubations

The inhibitory effects of prostaglandin $F_{2 \alpha}$ are reversible with high doses of human chorionic gonadotropin (Text Figure 8).

Text Figure 8

ANTAGONISM OF PROSTAGLANDIN $F_{2 \alpha}$ INHIBITION BY HUMAN CHORIONIC GONADOTROPIN

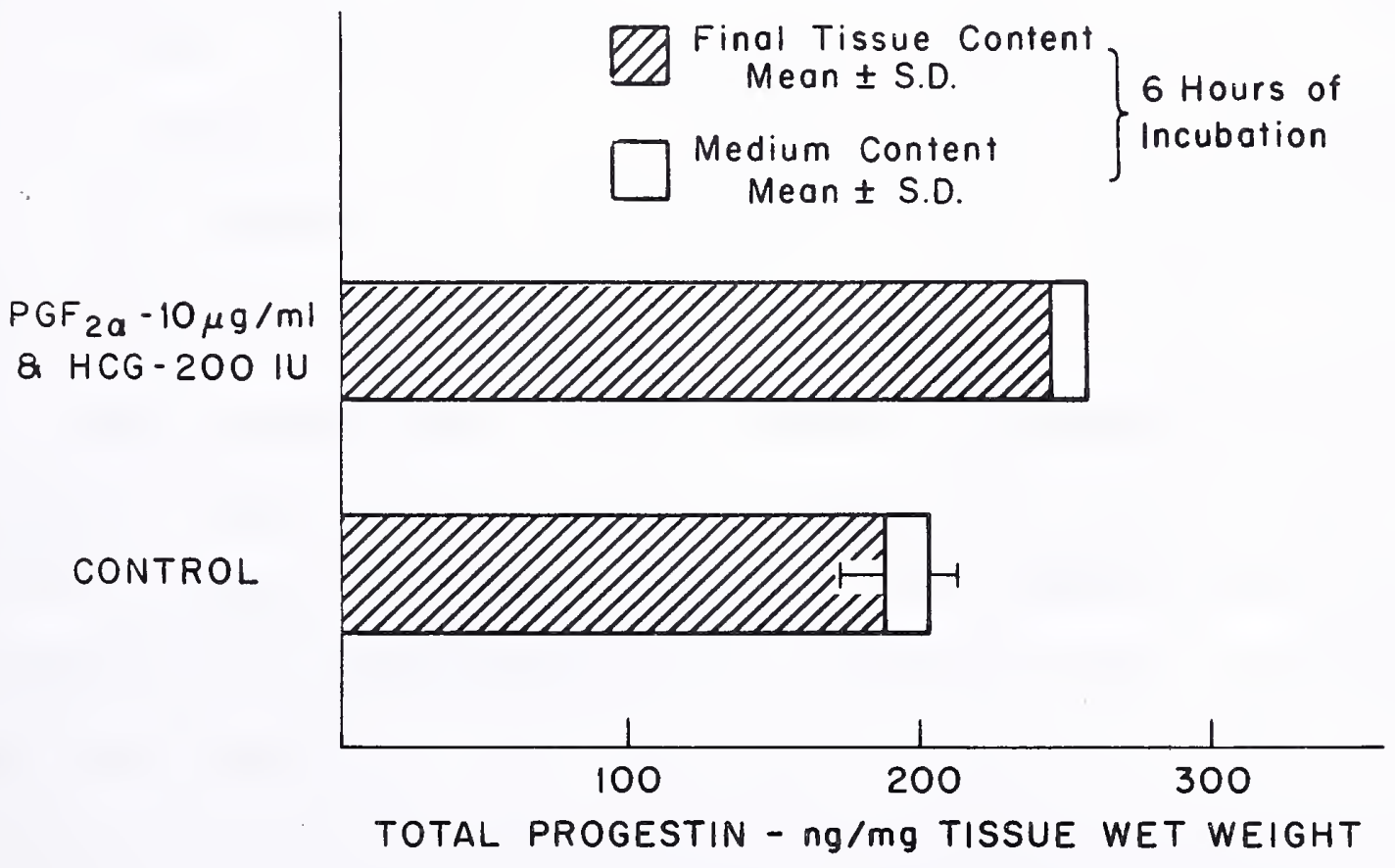





\section{DISCUSSION}

\section{Rabbit Reproductive Physiology}

Ovulation, Implantation and Pregnancy

The rabbit is a reflex ovulator. Coitus or vaginal stimulation initiates a neural impulse which travels to the hypothalamus and releases LH releasing factor (LRF) which causes a sub-ovulatory rise in circulating LH. This initial LH surge apparently stimulates the interstitum of the ovary to produce steroids, primarily $20 \alpha \mathrm{OH}$ progesterone $(\mathrm{Hi} 17 \mathrm{iard}$ et a7, 1967). Following this early peak in $20 \alpha \mathrm{OH}$ progesterone a second, ovulatory dose of LH is released from the pituitary (Hilliard et a], 1969; Scaramuzzi et a7, 1972). Ovulation then follows at about 10-12 hours post-coitus (Text Figure 9).

That an ovarian contribution is necessary for ovulatory leve] LH release is supported by the fact that in animals ovariectomized post mating LH drops sharply within 30 minutes. A7so, administering $20 \alpha \mathrm{OH}$ progesterone to ovariectomized animals increases the initial transient $L H$ peak that occurs within 1 hour post mating (Hilliard et a1, 1969). 



\section{Text Figure 9}

STEROIDS AND GONADOTROPIN LEVELS IN NORMAL RABBITS

STEROID AND GONADOTROPIN LEVELS IN NORMAL RABBITS

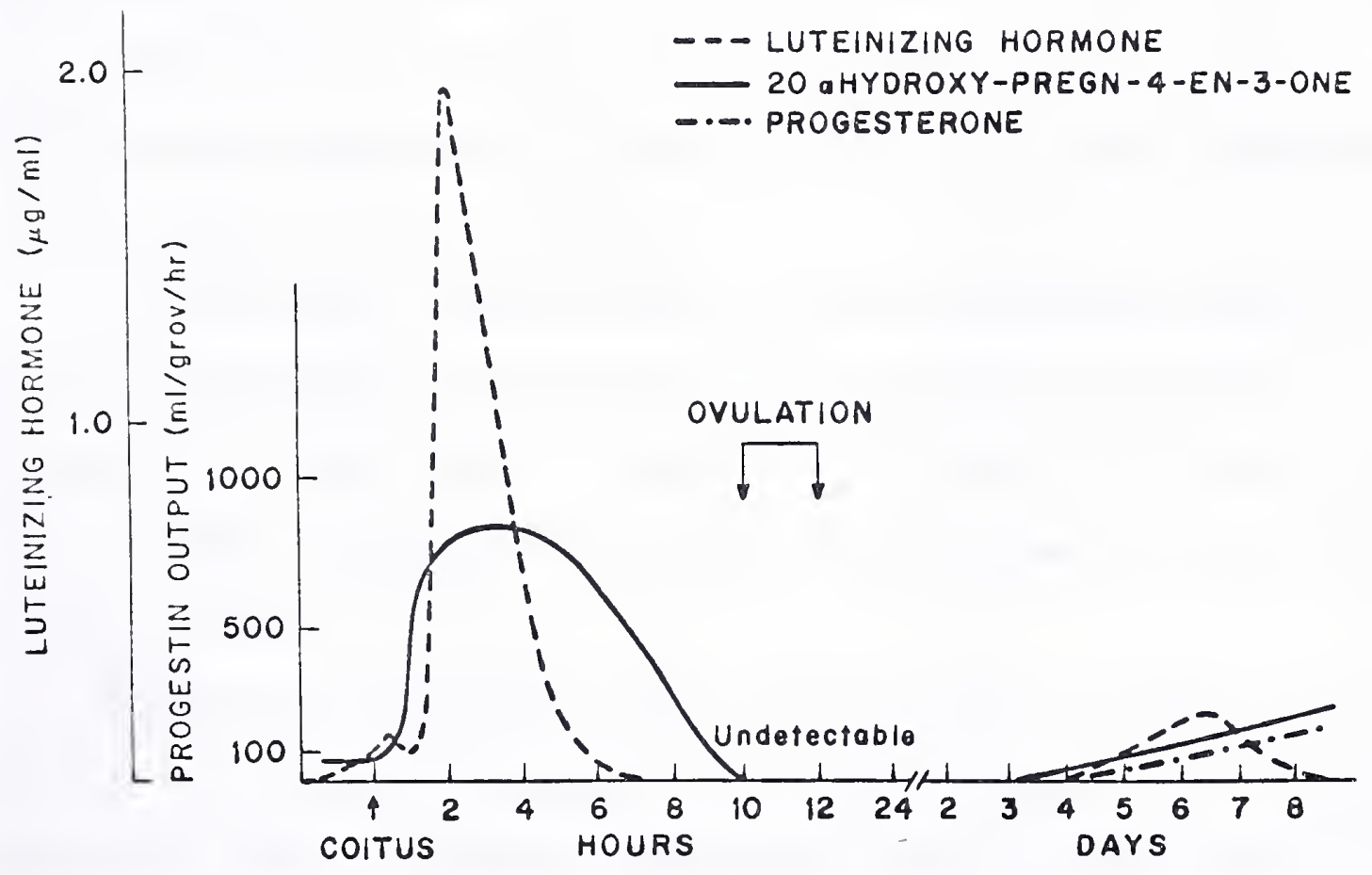



After ovulation there then follows a "silent period" until day 5 or 6 . During this interva1, progesterone, $20 \alpha \mathrm{OH}$ progesterone, $\mathrm{LH}$, and estrogen fall to baseline levels until just prior to the time of implantation, day 5 or 6 .

Estrogen is highest 2-3 hours post mating then drops precipitous $7 y$ by the 10th hour to very low levels and does not rise again until day 4, when it begins to rise slowiy.

When implantation occurs, estrogen is present, $20 \alpha \mathrm{OH}$ progesterone and LH have risen s7ight7y. LH subsequentiy makes a minor peak on day 6-7.

Norma 7 rabbit ovulation is thus an exceedingly complex event, dependent upon hypotha7amic, pituitary, ovarian, and vaginal communication, both neurogenic as well as humorat.

The rapid drop in gonadotropin and steroid levels post ovulation suggests that the 4-5 day period of tubal transport is apparent7y independent of normal steroid contro1. As Hi17iard (1971) points out, tubar transport occurs during and after a period of acute withdraw 1 of ovarian steroids.

B7astocyst implantation usual7y occurs on day 5 of 6 (Hit7iard et a7, 1969). At the same time progesterone and $20 \alpha \mathrm{OH}$ progesterone rise and continue to rise to a plateau between days 15-20 and then slowiy fall. During the period of greatest ovarian activity, days $15-20$, corpus Tuteum gross weight is maximal and progesterone output exceeds $20 \alpha \mathrm{OH}$ progesterone production.

In norma 7 rabbit pregnancy, the placenta apparentiy has little role in the maintenance of gestation; however, the continued presence of both the pituitary and the ovaries is required during the entire 30-32 day period 

of rabbit gestation (Hilliard, et a7, 1969; Dorrington \& Kilpatrick, 1969) Hypophysectomy in eariy pregnancy or pseudopregnancy results in corpus Tuteum atrophy within 4 days. Similarly, removal of the pituitary in the second half of gestation leads to rapid abortion (Hilliard et a1, 1969).

Corpus Luteum Function

In the rabbit, the major ovarian steroid products are progesterone and $20 \alpha \mathrm{OH}$ progesterone. In the corpus Tuteum, the major product is progesterone (Greenwald \& Rothchild, 1968) whereas in interstitial tissue, the production of $20 \alpha$ OH progesterone predominates (Dorrington \& Kilpatrick, 1969). A smali but important amount of estrogen is also produced predominately by the theca-foliticular cells, not the corpus luteum (Armstrong, 1968; Short et a1, 1962; Falck, 1959). This estrogen is required to support the stimulatory effects of LH (Keyes \& NaTbandov, 1967) and is necessary for normal corpus Tuteum function during pregnancy. In studies where $X$ irradiation was utilized to destroy follicular tissue in one ovary (Keyes \& Armstrong, 1968; Nalbandov, 1970) corpora Tutea regressed and abortion occurred following the removal of the normal, contralateral ovary. In similar studies, progestin alone and LH alone or in combination with Prolactin failed to prevent corpus luteum regression post unilateral irradiation and contralateral ovectomy.

In animals hypophysectomized during the second week of gestation, follicular involution and corpus Tuteum regression was rapid and could not be prevented by LH, FSH or Prolactin (Spies et a T, 1968).

However, progestin output and luteal morphology were maintained by estradiol in hypophysectomized animals and corpus Tuteum maintenance comparable to intact, pregnant controls was achieved with an estradiol/prolactin mixture. 

In sum, in normal rabbit reproductive physiology, estrogen acts at the ovary, sustaining the structure and function of the corpus luteum. The effects of progesterone are uterine and maintain a progestational endometrium during gestation. The role of $20 \alpha \mathrm{OH}$ progesterone appears to be closely tied to the process of ovulation. The rise in $\mathrm{LH}$ initiated by coitus induces $20 \alpha \mathrm{OH}$ progesterone production by interstitial cells and the preovulatory release of this progestin apparentiy exerts a positive feedback action on LH discharge (Hi7liard, 1969).

Role of Prostaglandins

Prostaglandins and Ovulation

The experimental evidence presented in this study indicates that prostaglandins are involved with the process of ovulation. The present studies with indomethacin and other recent work (Orczyk \& Behrman, 1972; Grinwich et a1, 1972; Armstrong \& Grinwich, 1972) show inhibition of normal ovulatory response in treated animals. In addition, Kueh7's work (Kuehl et a1, 1970) shows that the ovarian response to LH in steroidogenesis and CAMP content can be blocked with another prostaglandin synthesis antagonist, 7-oxa-13-prostynoic acid.

However, a major disagreement in these studies concerns the site of action of the ovulatory blockade. Grinwich and Armstrong (Grinwich et a 7 , 1972) report that $L H$ was able to induce ovulation in rats previously blocked with indomethacin, while Orczyk and Behrman (1972) were unable to overcome this block, utilizing luteinizing hormone.

In the present studies, the blockade of coitually induced rabbit ovulation by indomethacin indicates that the ovarian ovulatory mechanism 

is inhibited and not the release of endogenous LH or steroids. Egg rupture from ovarian follicles is prevented by single dose indomethacin (20 mg/kg iv) 8 hours after mating. However, indomethacin at the time of mating or prolonged indomethacin treatment prior to mating is ineffective and normal ovulation occurs. This is explained by the fact that a dose of indomethacin administered prior to or with coitus would have been largely excreted ( $\leq 4$ hours) (Hucker et a 1, 1966) by the time normal ovulation would occur (10-12 hour delay).

However, in the rabbit it is known that coitus induces an LH surge within 90 minutes (Hilliard, personal communication; Scaramuzzi et a 1,1972 ) and that ovulation occurs 9 hours or more later. Thus, the initial peak of LH must have occurred in the pre-coitally treated animals despite the presence of an inhibitor of prostaglandin synthesis.

The case for an ovulatory blockade at the ovarian level is strengthened by the fact that ova were found histologically in hemorrhagic follicles in those animals in whom ovulation had been blocked (Text Figure 4).

In comparable studies in the rabbit, Armstrong's group developed similar hemorrhagic follicles with retained ova in their animals treated with indomethacin who failed to ovulate (Grinwich et al, 1972).

The discovery of luteal change occurring in hemorrhagic follicles with retained ova and the normal progestin levels found in these animals also supports the contention that LH release and the effects of LH upon steroidogenic cells were not blocked by indomethacin treatment. The persistence of apparentiy normal ovarian steroid production in ovulatory blocked rabbits suggests that indomethacin treated cycles are infertile due to a selective inhibition of egg extrusion while at the same time normal in 

hormonal secretion and perhaps also normal in duration.

The failure of single dose indomethacin treatment to block HCG stimulated ovulation is probably explained by the relative half-lives of the two drugs. Indomethacin has a half-life of approximately 4 hours in the rabbit and is largety excreted in the urine (Hucker et a 1, 1966). In contrast, HCG has a short half-iife of 4 hours, and a 24-36 hour long half-life.

Thus, an ovulatory dose of HCG probably remains active after the PG blockade of indomethacin has dissipated. This hypothesis is supported by the observation that indomethacin treatment before HCG stimulation plus post stimulation treatment was successfur in the inhibition of ovulation.

LH with its brief half-life is not subject to this delayed ovulatory effect. Therefore, LH/indomethacin treated animais failed to ovulate.

Prostaglandins and Corpus Luteum Regression

A basic question in reproductive physiology has concerned attempts to elucidate the mechanism of corpus luteum regression. Recent evidence strongly implies that prostaglandins released from the uterus may be the active agents in terminating corpus luteum function in many subprimate mammatian species.

Pharriss (1971) in his discussion of the mechanism of prostaglandin mediated luteolysis mentions as possible explanations, direct feedback on the pituitary gland, "antigonadotropic" effects, stimulation of uterine "Tuteolysins", direct corpus Tuteum toxicity, and utero-ovarian vein constriction. Of these possibilities, uterine "luteolysins" and direct or anti-gonadotropic actions are the best candidates to explain the mechanism of corpus iuteum regression. 
There has been a lengthly search for a luteolysin of uterine origin since Loeb first reported extended corpus luteum survival in hysterectomized guinea pigs in 1923. Similar findings have since been reported in the rat, hamster, sheep, cow, pig and rabbit (Schomberg, 1967; Caldwe11, 1969a, 1969b, 1970b, 1970c; Anderson et a 1, 1969).

The presence of a uterine derived substance capable of acting upon the corpus luteum has been best documented in the sheep (Moor \& Rowson, 1966). Ovine uterine vein plasma acquires a luteolytic property on day 14 of the norma 7 cycle. This ability is absent in day 8 plasma or in day 14 jugutar blood (Caldwel1 \& Moor, 1971). The fact that these luteolytic effects are dependent on maintenance of normal vascular connections between ovary and uterus (Howe, 1965; Inskeep \& Butcher, 1966) suggests that a loca77y active substance is secreted from the uterus to exert an inhibitory effect on the ovary. It is probable that this substance which has a uterine origin, a brief half-life, and very local activity is a prostaglandin.

Pharriss explained the Tuteolytic action of prostaglandin $F_{2 \alpha}$ in vivo by proposing that ovarian blood flow was restricted by the potent venoconstrictive property of prostaglandin $F_{2 \alpha}$ producing ovarian ischemia and inhibition of steroid production (Pharriss, 1970, 1971). However, several recent studies fail to substantiate this hypothesis.

Behrman and co-workers (1971a) found no changes in ovarian venous flow rates in the rat despite a marked decrease in progesterone secretion after prostaglandin $F_{2 \alpha}$ administration.

McCracken's (1971) studies in the sheep show that intravenous PGF $2 \alpha$ infusion transiently increases blood flow and progestin production. This initial stimulation of steroidogenesis was followed by regression to less than $50 \%$ of control values within 1 hour. Ovarian blood flow did not fall 

below control values until 48 hours, yet at 24 hours progesterone output had already declined to undetectable levels.

Studies by Speroff et al (personal communication) utilizing the corpus luteuni of the monkey (Erythrocebus patas) support a direct ovarian effect of prostaglandins and $P G$ antagonism with gonadotropins. Animals super-ovulated with Pergonal and HCG were infused with PGF $2 \alpha$ while ovarian vein effluents were collected. Low doses of $P G F_{2 \alpha}(1-10 \mathrm{ng} / \mathrm{min})$ given intravenously at the periphery stimulated progesterone output as did similar intra-aortic doses. In contrast, high doses of $\mathrm{PGF}_{2 \alpha}(1-50 \mathrm{ng} / \mathrm{min})$ inhibited steroidogenesis and were associated with a decline in CAMP tissue content despite absence of change in blood flow. The inhibitory effects of $P G F_{2 \alpha}$ were reversible with $H C G$.

In sum, this evidence makes Pharriss' venoconstrictive hypothesis less likely as the major mode for corpus luteum regression.

In the present in vivo studies, the lifespan of the corpus luteum of pseudopregnancy was significantly lengthened well beyond the usually cited 16-17 day period by $P G$ synthesis inhibition with indomethacin (Greenwald \& Rothchild, 1968).

Table IV compares the effects of hysterectomy, indomethacin treatment, and $\mathrm{PGF}_{2 \alpha}$ immunization on corpus luteum lifespan. The marked similarity in the prolongation of corpus luteum survival in these three studies is striking, and strongly suggests that a single mechanism may explain these observations. 

Table IV.

THE LENGTH OF PSEUDOPREGNANCY IN RABBITS HYSTERECTOMIZED, IMMUNIZED AGAINST PROSTAGLANDIN $F_{2 \alpha}$ AND TREATED WITH INDOMETHACIN

\begin{tabular}{lcc} 
GROUP & CYCLES & DURATION OF PSEUDOPREGNANCY ${ }^{1}$ \\
\hline Controt & 10 & $16 \pm 0.5$ days \\
Hysterectomized $^{2}$ & & $25-29$ days \\
Immunized $^{3}$ & 5 & $25 \pm 1.2$ days \\
Indomethacin $^{4}$ & 4 & $24-29$ days \\
\hline
\end{tabular}

1 Determined by plasma progesterone determinations

2 Anderson et a1, 1969

3 Unpublished data, Caldwell et al

4 summary of data, text figure IX 

This evidence is interpreted as supporting the hypothes is that corpus luteum regression in the rabbit is mediated through prostaglandins which act directly upon the luteal cell to decrease progestin synthesis. In addition, this inhibition may be reversed with gonadotropins, primarily HCG. The results also indicate that the dose of indomethacin used is effective in the inhibition of prostaglandin synthesis. The extension of pseudopregnancy to about the same extent as produced by hysterectomy represents additional evidence that the uterus is responsible for $\mathrm{PGF}_{2 \alpha}$ production and regulation of ovarian periodicity. Collaborative in vitro experiments make a venoconstrictive mechanism for rabbit corpus luteum regression unlikely.

Prostaglandins and Normal Pregnancy

The meaning of implant regression with gross degereration in normally pregnant animals treated with indomethacin is unclear. Similar effects have been long known as the results of acetyl salicylic acid treatment in mice (Lamont-Havers, 1968) and may represent direct drug toxicity on developing embryos. This effect may also be representative of interference with basic developmental PG dependent processes in an unknown manner.

Mechanism of Action of Prostaglandins on

Luteal Cell Function

The elegant studies of Behrman (1971c) suggest a scheme for direct prostaglandin and gonadotropin control of corpus luteum function. Central to this model is the concept that control of the availability of the major substrate for steroid biosynthesis, "free cholesterol", is of primary 

importance. Prostaglandin $F_{2 \alpha}$ and gonadotropins LH and Prolactin (in the rat at least) act predominately in regulating the availability of substrate for the biosynthetic steroid machinery (Text Figure 10).

Text Figure 10

CONTROL OF CORPUS LUTEUM BIOSYNTHESIS AT THE CELLULAR LEVEL

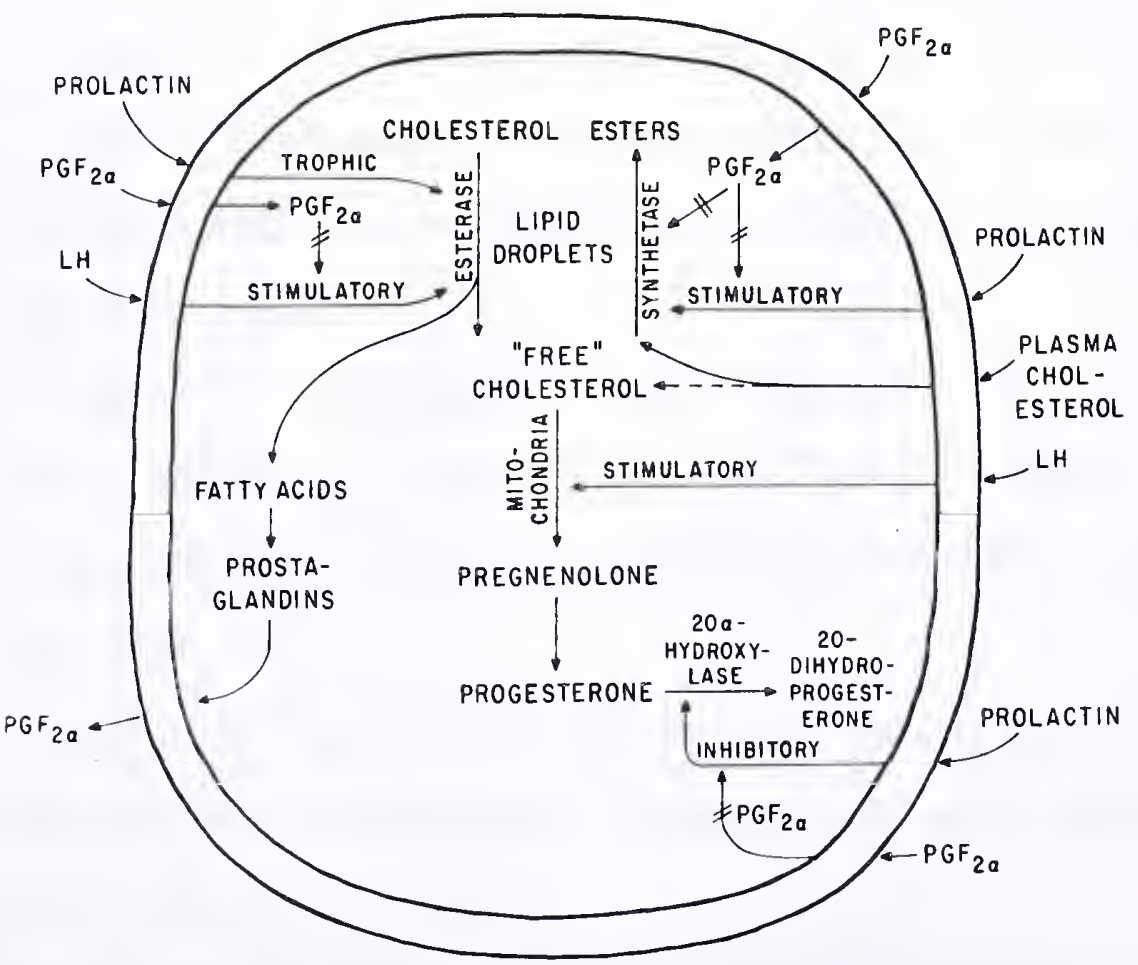

(Based on data from Behrman) 

The availability of "free" cholesterol for steroidogenesis depends primarily upon the movement of cholesterol from an intracellular pool of cholesterol ester. Passage from ester or plasma to an active form of cholesterol is enzyme mediated.

Cholesterol esters are converted to the "active" form by cholesterol ester esterase. This "free" cholesterol then enters the progestin pathway and steroidogenesis occurs. Experiments with LH antiserum show that steroidogenesis occurs in the absence of LH, suggesting that cholesterol oxidation may be dependent not primarity on LH but on simple substrate availability.

$P_{\text {GF }}$ acts to prevent cholesterol ester from entering the pool of "free" cholesterol by inhibiting cholesterol esterase activity, yet this effect is easily overcome by $\mathrm{LH}$ and prolactin. The principal PGF $2 \alpha$ effect is to inhibit cholesterol ester synthetase and block the effects of prolactin on this enzyme.

Thus, the decline in progesterone output noted with $\mathrm{PGF}_{2 \alpha}$ administration is due to depletion of stored cholesterol ester secondary to synthetase enzyme blockade in the face of continued and even increased progestin production.

$\mathrm{PGF}_{2 \alpha}$ treatment is known to increase $2 \mathrm{O}_{\alpha} \mathrm{OH}$ progesterone output and this effect may represent prostaglandin antagonism of the $20_{\alpha}$ hydroxylase enzyme normally inhibited by Prolactin.

The present organ culture experiments utilizing the corpus luteum of the rabbit and studies with the rat (Behrman, In Press) support a direct prostaglandin action on the corpus luteum, which can be understood through reference to Behrman's scheme.

Both studies show that $\mathrm{PGF}_{2 \alpha}$ acts to inhibit progestin synthesis. 

In the in vitro rabbit studies where segments of corups luteum were incubated in a modified organ culture system $10 \mathrm{mg} / \mathrm{ml}$ of $\mathrm{PGF}_{2 \alpha}$ in the incubating medium inhibited progestin production by $50 \%$.

In this system, LH alone did not significantly stimulate progestin synthesis, as has been found by other workers (Dorrington \& Kilpatrick, 1966). Also, the inhibitory effects of $\mathrm{PGF}_{2 \alpha}$ were reversible with high doses of HCG (APL) (Text Figure 8).

The failure of LH to stimulate progestin production and to inhibit $\mathrm{PGF}_{2 \alpha}$ mediated luteolysis may reflect the need for estrogen for normal LH function in the rabbit.

\section{CONCLUSIONS}

The results of these studies demonstrate that indomethacin can block the physical process of ovulation at the ovarian level, and can prolong the functional lifespan of rabbit corpora lutea during pseudopregnancy.

Both of these effects are the result of potent inhibition of prostaglandin synthesis. This necessarily implies that prostaglandins are directly involved in both the ovulatory process and the control of corpora lutea function in the rabbit.

The ability of indomethacin to interfere with normal pregnancy must be viewed with caution. It remains to be determined whether this represents prostaglandin synthesis inhibition, thus assuming that prostaglandins are in some manner essential to fetal survival, or simply direct fetal toxicity.

As the timing of indomethacin administration was critical for the blockade of ovulation it is unlikely that this effect can be related to drug toxicity. This is supported by the observation that even high doses at certain times were ineffective and normal ovulation occurred. 

Potential7y, the most important suggestion from these studies is the possibility that normal patterns of ovarian steroidogenesis may be maintained despite blockage of the physical process of ovulation. In other words, $P G$ synthesis inhibition with ovulatory blockade may provide functional sterility with biochemical normality. 

BIBL IOGRAPHY 

Amoss, M., Blackwe11, R., Vale, W., Burgus, R. and Guillemir, R.

1971 Inter. Cong.Phys. Sci., Abstract 37, 9:17.

Anderson, G.G., Hobbins, J.C., Rajkovic, Vladimir, Speroff, Leon, and Caldwel1, B.V.

1972

"Midtrimester Abortion Using Intraamniotic PGF $2 a . "$ Prostaglandins, $1: 2$.

Anderson, L.L., Bland, K.P. and Melampy, R.M.

"Comparative Aspects of Uterine Luteal Relationship."

1969

Rec. Prog. Horm. Res. 25:51.

Armstrong, David T.

1968

"In vitro Synthesis of Progesterone."

VII Biennial Symposium on Animal Reproduction, J. Anim. Sci. 27:Supplement I.

Armstrong, David T., and Grinwich, Daniel L.

"Blockade of Spontaneous and LH Induced Ovulation in Rats

1972

by Indomethacin, An Inhibitor of Prostaglandin Biosynthesis." Prostaglandins, $1: 1$.

Behrman, H.R., Yoshinaga, K., and Greep, R.0.

"Extraluteal Effects of Prostaglandins."

1971 (a) Ann. N.Y. Acad. Sci. 180:426.

Behrman, H.R., Yoshinaga, K. and Greep, R.0.

"Effects of Prostaglandin on Ovarian Steroid Secretion and 1971 (b) Biosynthesis During Pregnancy." Am. J. Physiol. 221:189.

Behrman, H.R., MacDonald, G.J., and Greep, R.0.

"Regulation of Ovarian Cholesterol Esters: Evidence for 1971(c) the Enzymatic Sites of Prostaglandin Induced Loss of Corpus Luteum Function."

Lipids, (In Press).

Bergstrom, S., Bygdeman, M., Samuelsson, B. and Wiqvist, N.

1971

"The Prostaglandins and Human Reproduction."

Hospital Practice, February.

BTand, K.P. and Donovan, B.T.

"The Uterus and the Control of Ovarian Function."

in: Advances in Reproductive Physiology, Vol 1., Ed.

A. McLaren. London: Academic Press. 

Butcher, R.W., and Baird, C.

1968 Levels in Fat and Other Tissues."

J. Biol. Chem. 243:1713.

Bygdeman, M. and Wiqvist, N.

"Early Abortion in the Human."

1971 Ann. N.Y. Acad. Sci. 180:473.

Caldwe11, B.V., Moor, R.M., Wilmut, I., Polge, C. and Rowson, L.E.A., "The Relationship Between Day of Formation and Functional 1969(a) Life Span of Induced Corpora Lutea in the Pig." J. Reprod. Fert. 18:107.

Caldwe11, B.V., Rowson, L.E.A., Moor, R.M. and Hay, M.F. 1969(b) "The Utero-Ovarian Relationship and its Possible Role in

J. Reprod. Fert. Supplement 8:59.

Caldwe11, B.V.

"Physiological Studies Using Antibodies to Steroids."

1970(a). In: Immunological Methods in Steroid Determination,

Ed. F. G. Péron and B.V. Caldwe71, New York: AppletonCentury-Crofts.

Caldwe11, B.V.

1970(b) Periodicity."

In: Sonderdruck aus21. Colloguium der Gesellschaft fur Biologische Chemie 9-11 April, 1970, Mosbach/Baden. Berlin: Springer-Verlag.

Caldwe11, B.V. 1970(c) Iterine Factors Influencing Corpus Luteum Function.
In: Advances in Biosciences, Vo , 4. Ed. G. Raspe Vieweg: Pergamon Press.

Caldwe17, B.V. and Moor, R.M.

"Further Studies on the Role of the Uterus in the Regulation of Corpus Luteum Function in Sheep." J. Reprod. Fert. 26:133.

Dorrington, J.H. and Kilpatrick, R.

"Effects of Pituitary Hormones on Progestational Hormone 1966 Production by the Rabbit Ovary In Vivo and In Vitro." J. Endocr. $35: 53$. 

Dorrington, J.H., Kilpatrick, R.

"The Synthesis of Progestational Steroids by the Rabbit

1969. Ovary." In: The Gonads, Ed. K.W. McKerns New York: Appleton-Century-Crofts.

Falck, B.

1959

"Site of Production of Oestrogen in Rat Ovary as Studied in Microtransplants."

Acta. Physio7. Scand. 47: Supplement 163.

Ferreira, S.H. and Vane, J.R.

"Prostaglandins: Their Disappearance from and Release into

1967 the Circulation." Nature 216:868.

Ferreira, S.H., Moncada, S. and Vane, J.R.

"Indomethacin and Aspirin Abolish Prostaglandin Release

1971 from the Spleen" Nature New Biol. 231,237, June 23.

Field, J.B., Zor, U. and Kaneko,T.

"Effects of TSH, LATS, and Prostaglandin E on Dog Thyroid

1969 Adeny 1 Cyclase Activity (ACA) and Cyclic $35^{\prime}$ Adenosine Monophosphate (CAMP)."

Abs. 57st. Mtg. Endocr. Soc. (New York): 98

Ginther, 0.J.

1967

"Local Utero-Ovarian Relationships."

J. Anim. Sci. 26:678,

Greenwa 7d, G.S., and Rothchi7d, I.

"Formation and Maintenance of Corpora Lutea in Laboratory Anima 1s."

VIII Biennial Symposium on Animal Reproduction, J. Anim. Sci. Supplement

Grinwich, D.L., Kennedy, T.G., and Armstrong, D.T.

"Dissociation of Ovulatory and Steroidogenic Actions

1972

of Luteinizing Hormone in Rabbits with Indomethacin, An Inhibitor of Prostaglandin Biosynthesis."

Prostaglandins, 1:2.

Hilliard, J.E., Hayward, J.N., and Sawyer, C.H. "Postcoital Patterns of Secretion of Pituitary Gonadotropin and Ovarian Progestin in the Rabbit." Endocrinology, 75:957. 

Hilliard, J.E., Penardi, R., and Sawyer, C.H.

"A Functional Role for $20 \alpha$ hydroxypregn-4-en-3-one 1967

in the Rabbit."

Endocrinology, 80:901.

Hiliiard, J.E., Spies, H.G., and Sawyer, C.H.

"Hormonal Factors Regulating Ovarian Cholesterol Mobilization

1969 and Progestin Secretion in Intact and Hypophysectomized Rabbits."

In: The Gonads, Ed. K.W. McKerns, New York: AppletonCentury-Crofts, 1969.

Hilliard, J.E. and Eaton, L.W. Jr.

"Estradiol $17 \beta$ Progesterone and 20 Hydroxypregn-4-en-3-one

1971

in Rabbit Ovarian Venous P7asma. II: From Mating Through Implantation."

Endocrinology, 89, No. 2:522.

Howe, G.R.

1965

"Influence of the Uterus upon Cyclic Ovarian Activity in the Guinea Pig."

Endocrinology, 77,472.

Howe, G.R.

1968

"The Uterus and Luteal Activity in the Rat, Hamster, and Rabbit."

Fert. and Ster. 19:6, 936.

Hucker, H.B., Zacche1, A.G., Cox, S.V., Brodie, D.A. and Cantwe11, N.H.R. "Studies on the Absorption, Distribution and Excretion of

1966 Indomethacin in Various Species."

J. of Pharm. Exp. Therap. 153:2.

Inskeep, E.K. and Butcher, R.L.

"Local Component of Utero-Ovarian Relationships in the Ewe."

1966 J.Anim. Sci. 25, 1164.

Karim, S.M. and Filshie, G.M.

$1970 \quad$ Lancet, $7: 157$.

Karim, S.M. 

Keyes, P.L., and Nalbandov, A.V.

"Maintenance and Function of Corpora Lutea in Rabbits

1967 Depend on Estrogen."

Endocrinology, 80,938 .

Keyes, P.L. and Armstrong, D.T.

"Endocrine Role of Follicles in the Regulation of

1968

Corpus Luteum Function in the Rabbit."

Endocrinology, 83:3,509.

Kilpatrick, R. Armstrong, D.T., and Greep, R.0.

"Maintenance of the Corpus Luteum by Gonadotrophins

1964

in the Hypophysectomized Rabbit."

Endocrinology 74,453,

Kuehl, F.A., Humes, J.L., Tarnoff, J., Cirillo, V.J. and Ham, E.A.

"Prostaglandin Receptor Site: Evidence for an Essential

1970

Role in the Action of Luteinizing Hormone."

Science, $169: 3948,883$.

Labhsetwar, A.P.

"Effects of Prostaglandin $F_{2 \alpha}$ on Pituitary Luteinizing Hormone

1970 Content of Pregnant Rats: A Possible Explanation for the Luteolytic Effect."

J. Reprod. Ferti]. 23, 155.

Lamont-Havers, R.W. and Wagner, B.M., editors. Proceedings of the Conference 1968 on Effects of Chronic Salicylate Administration, June 13-74, 1966, New York, N.Y. U.S. Dept. H.E. \& W., NIH, Nat. Inst. of Arthritis and Metabolic Diseases, Washington: Us. Gov't Printing Office.

Large, B.J., Leswe11, P.F. and Maxwe11, D.R.

"Bronchodilator Activity of an Aerosel of Prostaglandin $E_{7}$

1969 in Experimental Animals."

Nature, 224,78, October 4.

Lee, J.B.

1967

In: Nobel Symposium 2: Prostaglandins, Ed. S. Bergstrom and B. Samuelsson.

Stockholm: Almqvist \& Wiksell.

Lippman, W.

"Inhibition of Gastric Acid Secretion in the Rat by Synthetic Prostaglandin Analogues."

Ann. N.Y. Acad. Sci., 180:332. 

Loeb, L. Function of the Corpus Luteum in the Guinea Pig. " Proc. Soc. Exp. Biol. 20, 1441.

Marsh, J.M.

1970

"The Stimulatory Effect of Luteinizing Hormone on Adenyl Cyclase in the Bovine Corpus Luteum."

J. Biol. Chem. 245,1596,

Marsh, J.M.

1971

"The Effect of Prostaglandins on the Adenyl Cyclase of the Bovine Corpus Luteum."

Ann. N.Y. Acad. Sci. 180,416 .

McCarcken, J.

1971

"Prostaglandin $F_{2}$ and Corpus Luteum Regression."

Ann. N.Y. Acad. Sci., 180:456.

McGiff, J.C., Crowshaw, K., Terragno, N.A. and Lonigro, A.T.

"Release of a Prostaglandin-like Substance into Renal Venous

1970 Blood in Response to AngiotensinII."

Circ. Res.27:Supp 1. 1,121.

Moor, R.M. and Rowson, L.E.A.

"Local Uterine Mechanisms Affecting Luteal Function in

1966 the Sheep."

J. Reprod. Ferti1. 11,307.

O'Grady, J.P., Kohorn, E.I., Glass, R.H., Caldwe11, B.V., Brock, W.A. and Speroff, L.

1972

"Inhibition of In Vitro Progesterone Synthesis by

Prostaglandin $\mathrm{F}_{2 \alpha^{\circ}}$

J. Reprod. Fertî. (In Press).

Orczyk, G.P. and Behrman, H.R.

"Ovulation Blockade by Aspirin or Indomethacin- In Vivo

1972

Evidence for a Role of Prostaglandin in Gonadotrophin

Secretion."

Prostaglandins, $1: 1,3$.

Perrier, C.V. and Laster, L.

"Adenyl Cyclase Activity of Guinea Pig Gastric Mucosa:

1970

Stimulation by Histamine and Prostaglandins."

J. Clin. Invest. 49, 73a. 

Pharriss, B.B., Wyngardon, L.J., and Gutknecht, G.D.

1968

"Biological Interactions Between Prostaglandins and Luteotropins."

in Gonadotropins, Ed. E. Rosenberg, Los A7tos: Geron X.

Pharriss, B.B.

1970

"The Possible Vascular Regulation of Luteal Function." Perspect. Biol. Med. 13,434.

Pharriss, B.B.

1971

"Prostaglandin Induction of Luteolysis."

Ann. N.Y. Acad. Sci. 180,436 .

Pharriss, B.B., Tillson, S.A. and Erickson, R.R.

"Prostaglandins in Luteal Function."

1972

Rec. Prog. Hor. Res. (In Press),

Piper, P. and Vale, J.

"The Release of Prostaglandins from Lung and Other Tissues."

1971

Ann. N.Y. Acad. Sci, $180,363$.

Ramwe 1, P. and Shaw, J.

"The Biological Significance of the Prostaglandins."

1971

Ann. N.Y. Acad. Sci. , 180, 10 .

Scaramuzzi, R.J., Blake, C.A., Papkoff, H., Hilliard, J. and Sawyer, C.H.

1972 "Radioimmunoassay of Rabbit Luteinizing Hormone: Serum Leve]s During Various Reproductive States." Endocrinology, (In Press).

Schomberg, D.W.

1967

"A Demonstration In Vitro of Luteolytic Activity in Pig Uterine Flushings."

J. Endocr. 38, 359.

Shaw, J., Gibson, W., Jessup, S. and Ramwe11, P.

1971 Erythrocytes."

Ann. N.Y. Acad. Sci. 180:241.

Shio, H., Ramwe11, P.W. and Jessup, S.J.

"Prostaglandin $E_{2}$ : Effects on Aggregation, Shape Change

1972 and Cyclic AMP of Rat Platelets."

Prostaglandins , $7: 1,29$. 

Short, R.V.

1962

"Steroids in the Follicular Fluid and the Corpus Luteum of the Mare. A Two-Cell Type The ry of Ovarian Steroid Synthes is."

J. Endocr. 24,59.

Siggins, G., Hoffer, B. and Bloom, F.

"Prostaglandin-Norepinephrine Interactions in Brain:

1971 Microelectrophoretic and Histochemical Correlates." Ann. N.Y. Acad. Sci. 180,302.

Smith, J.B., and Willis, A.

"Aspirin Selectively Inhibits Prostaglandin Production in 1971 Human Platelets." Nature New Biology 231,235, June 23

Speroff, L. and Ramwe11, P.W. "Prostaglandins in Reproductive Physiology." 1970(a) Am. J. Ob. Gyn. 107:7,1111.

Speroff, L. and Ramwe11, P.W. "Prostaglandin Stimulation of In Vitro Progesterone Synthesis." 1970(b) J.C7in. Endocr. Metab. 30,345.

Speroff, Leon, Caldwe17, B.V., Brock, W.A., Anderson, G.G. and Hobbins, J.C. 1972 "Hormone Levels During Prostaglandin $F_{2 \alpha}$ Infusions for Therapeutic Abortion." J. End. Metab. 34:3,85.

Spies, H.G., Hilliard, J. and Sawyer, C.H.

"Maintenance of Corpora Lutea and Pregnancy in Hypophysectomized 1968 Rabbits." Endocrinology 83:354.

Vane, J.R.

1971

"Inhibition of Prostaglandin Synthesis as a Mechanism of Action for Aspirin-7ike Drugs." Nature New Biology, 231:232,

Wiqvist, N., Bygdeman, M.

"Therapeutic Abortion by Local Administration of Prostaglandin." 1970 Lancet, 2,716 . 







\section{YALE MEDICAL LIBRARY \\ Manuscript Theses}

Unpublished theses submitted for the Master's and Doctor's degrees and deposited in the Yale Medical Library are to be used only with due regard to the rights of the authors. Bibliographical references may be noted, but passages must not be copied without permission of the authors, and without proper credit being given in subsequent written or published work.

This thesis by has been used by the following persons, whose signatures attest their acceptance of the above restrictions. 


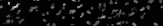

a

(1) 